Universidade de Brasília

FACULDADE DE ECONOMIA, ADMINISTRAÇÃO. CONTABILIDADE E CIÊNCIA DA INFORMAÇÃO E DOCUMENTAÇÃO - FACE

PROGRAMA DE PÓS-GRADUAÇÃO EM ADMINISTRAÇÃO - PPGA

WALDER RAYMUNDO FLORIANO JORGE

Um modelo baseado em processos organizacionais para o serviço de compras nacionais das IFES: o caso da UnB 
WALDER RAYMUNDO FLORIANO JORGE

\section{Um modelo baseado em processos organizacionais para 0 serviço de compras nacionais das IFES: o caso da UnB}

Dissertação apresentada ao Programa de Pós-Graduação em Administração da Faculdade de Economia, Administração, Contabilidade e Ciência da Informação e Documentação (FACE), da Universidade de Brasília, como requisito à obtenção do grau de Especialista em Gestão Universitária.

Orientador: Prof. Dr. Mamede Lima-Marques

Brasília-DF

2009 


\section{AGRADECIMENTOS}

Agradeço a Deus pelo dom da vida e pelas oportunidades oferecidas.

A todos aqueles que compartilharam os momentos felizes e os desafios desta caminhada, desde os bem próximos até aqueles mais distantes e que nem sequer sabemos seus nomes

A minha família, pelo apoio, união e compreensão.

Ao Professor Mamede Lima-Marques que com dedicação e esmero me orientou.

$\mathrm{E}$ aos professores pelo conhecimento transmitido, pela compreensão e incentivo e, em especial, ao Professor César Augusto Tibúrcio, que com seu entusiasmo conduziu todo curso e não poupou esforços para esclarecimentos quando isso se fez necessário. 


\section{RESUMO}

Este trabalho apresenta a análise do processo do pedido de compras de diferentes Instituições Federais de Ensino Superior, comparativamente à Universidade de Brasília, a partir de documentos consultados em meio eletrônico e/ou manuseados no setor responsável pelo processo. Apresenta uma revisão de literatura abordando aspectos como a conceituação de processos organizacionais e da gestão por meio de processos, a reengenharia de processos no contexto da estratégia institucional e vantagem competitiva, a tecnologia de informação e a gestão do conhecimento como características da reengenharia de processos, e a Administração Pública e sua necessidade de redução de custos exemplificada através da modalidade de licitação de Pregão Eletrônico. Na metodologia são explanadas etapas de um modelo de administração por processos, e posteriormente, nos resultados, são expostos os métodos do processo de pedido de compras de cada Universidade. Uma discussão, então, é realizada como análise dos dados obtidos, o que possibilitou a identificação de pontos fortes e pontos fracos no modelo de processos utilizado por cada Instituição de Ensino Superior. Suas principais considerações finais incluem a importância de estudos mais aprofundados em diferentes empresas, sejam elas privadas ou públicas de modo a se conhecer a eficiência e efetividade na execução dos processos e o desempenho das mesmas através da administração por processos por meio de descrição mais detalhada de suas diferentes etapas de execução.

Palavras-chave: Gestão por processo; Reengenharia de processo; Modelo de processo de compras; Instituições Federais de Ensino Superior. 


\section{LISTA DE QUADROS}

Quadro 1 - Espectro dos principais modelos de processos. .................................16

Quadro 2 - Exemplos de processos empresariais selecionados..........................18

Quadro 3 - Melhoria de Processos versus Reengenharia de Processos. .................21

Quadro 4 - Organização tradicional x Organização orientada para os Processos. ...22

Quadro 5 - Comparativo dos processos de compras das IFES, pesquisados..........71 


\section{LISTA DE FIGURAS}

Figura 1 - A organização tradicional, centrada em tarefas.....................................21

Figura 2 - A organização orientada para os Processos.......................................22

Figura 3 - Fluxo da metodologia da gestão por Processos. ……............................35

Figura 4 - Representação hierárquica dos agentes participantes do processo

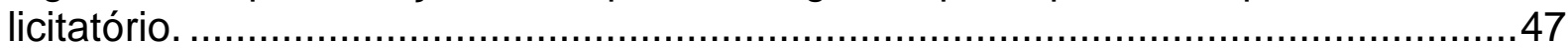

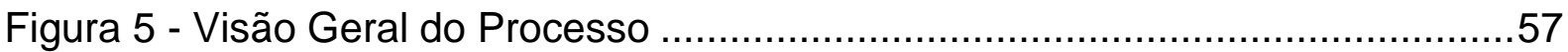

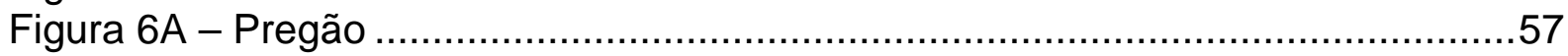

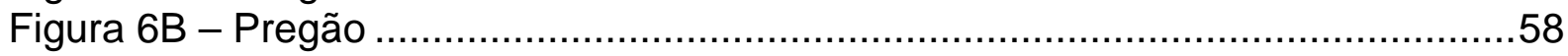

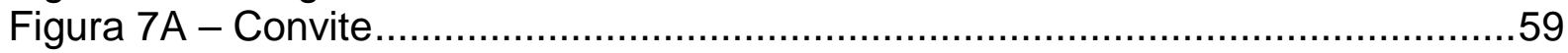

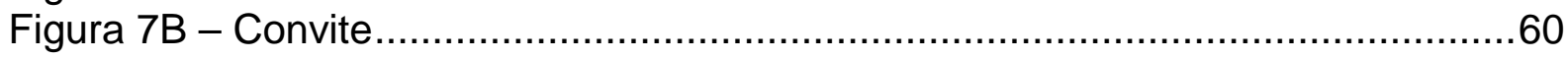

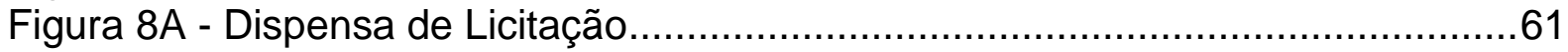

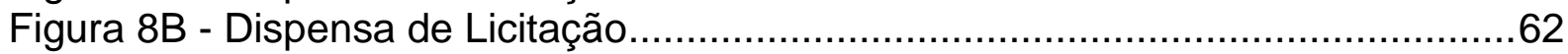

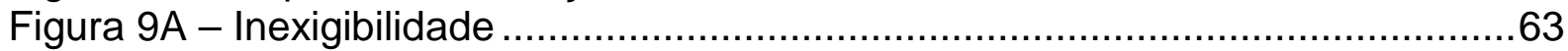

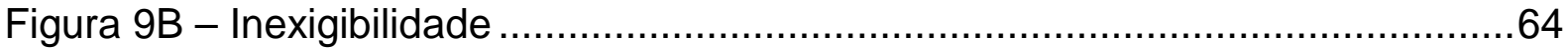

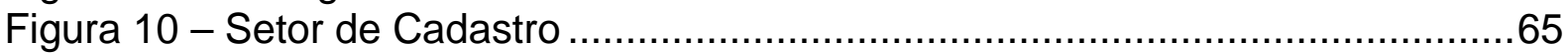

Figura 11 - Organograma do Setor de Compras .................................................65 


\section{LISTA DE SIGLAS}

AF- Autorização de Fornecimento

ASC- Área de Serviços Complementares

CAPES- Coordenação de Aperfeiçoamento de Pessoal de Nível Superior

CATMAT- Cátalogo Unificado de Materiais

CATSER- Catálogo Unificado de Serviços

CCF- Coordenadoria de Contabilidade e Finanças

CDOC- Controle de Documentação

CEB- Centro de Engenharia Biomédica

CEMEQ- Centro de Manutenção de Equipamentos

CME- Centro de Manutenção de Equipamentos

CNPq- Conselho Nacional de Desenvolvimento Científico e Tecnológico

CPEL- Comissão Permanente de Licitação

DAE- Decanato de Administração e Finanças

DCF- Diretoria de Contabilidade e Finanças

DRM- Diretoria de Recursos Materiais

E-gov- Governo Eletrônico

FGTS- Fundo de Garantia do Tempo de Serviço

FINEP- Financiadora de Estudos e Projetos

FUB- Fundação Universidade de Brasília

GEPRO- Grupo de Gestão de Processos

GRM- Gerência de Recursos Materiais

ICMS- Imposto sobre Circulação de Mercadorias e prestação de Serviços

IFES- Instituições Federais de Ensino Superior

INSS- Instituto Nacional do Seguro Social

MARE- Ministério da Administração Federal e Reforma do Estado

NE- Nota de Empenho

NEO- Nota Extra Orçamentária

PRDU- Pró- Reitoria de Desenvolvimento Universitário

SAL- Serviço de Almoxarifado

SCF- Seção de Cadastro e Controle de Fornecedores

SCN- Serviço de Compras Nacionais

SIASG- Sistema Integrado de Administração de Serviços Gerais 
SICAF- Sistema de Cadastramento Unificado de Fornecedores

SICON- Sistema de gestão de Contratos

SIDEC- Sistema de Divulgação Eletrônica de Compras

SIMAR- Sistema de Material e Serviço

SISME- Sistema de Minuta de Empenho

SISPP- Sistema de Preços Praticados

SMLP- Sistema Multiagente para Licitação Pública

TCESP- Tribunal de Contas do Estado de São Paulo

TCU- Tribunal de Contas da União

TI- Tecnologia de Informação

TIC's- Tecnologias de Informação e Comunicação

UFMS- Universidade Federal do Mato Grosso do Sul

UFSC- Universidade Federal de Santa Catarina

UnB- Universidade de Brasília

UNICAMP- Universidade Estadual de Campinas 


\section{SUMÁRIO}

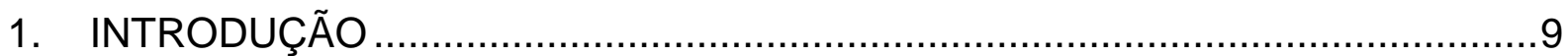

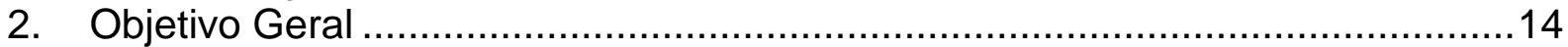

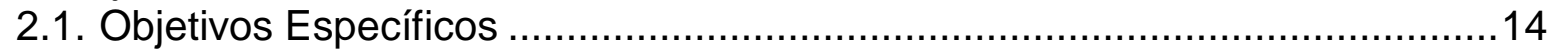

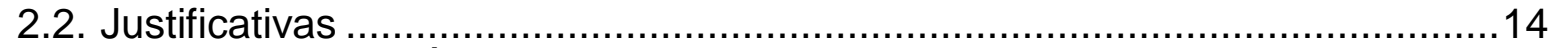

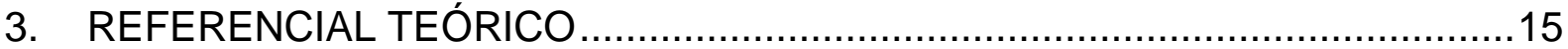

3.1. Processos organizacionais e gestão por processos: conceituação ................15

3.2. A reengenharia de processos como instrumento de melhoria de desempenho

organizacional.................................................................................. 19

3.3. Tecnologia da informação e Gestão do conhecimento na reengenharia de processos organizacionais..................................................................... 25

3.4. Administração pública e a necessidade de racionalização dos custos: Pregão

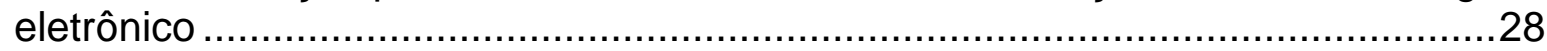

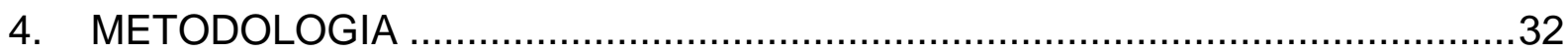

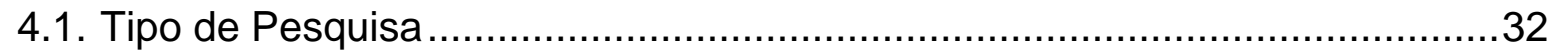

4.2. Referências consultadas para o delineamento dos Processos das Instituições

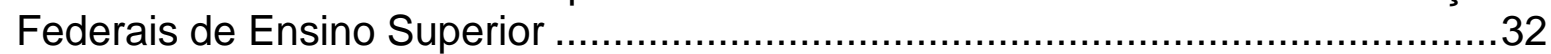

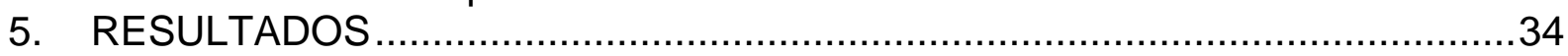

5.1. 1ำ caso: Universidade Estadual de Campinas- UNICAMP ..........................34

5.2. $2^{\circ}$ caso: relato do caso da Universidade Federal de Santa Catarina - UFSC. 45

5.3. $3^{\circ}$ caso: Universidade Federal de São Carlos- UFSCAR .............................47

5.4. $4^{\circ}$ caso: Universidade Federal de Mato Grosso do Sul- UFMS .....................48

5.5 O Modelo do Processo de Compras para Universidade de Brasília .................51

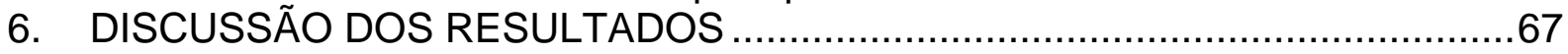

6.1. Análise dos processos de pedidos de compras das Instituições Federais de

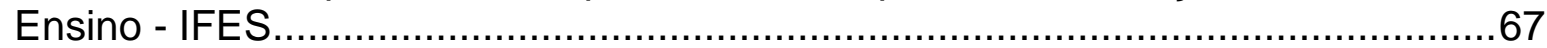

6.1.1. Um modelo de processo de compras ......................................... 71

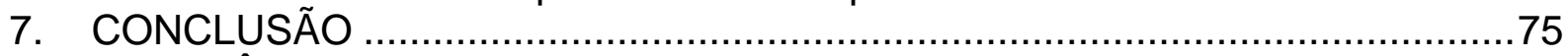

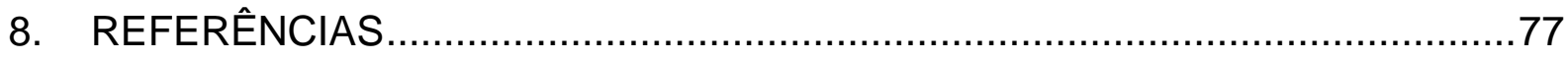




\section{INTRODUÇÃO}

As compras executadas pelo Serviço de Compras Nacionais da Universidade de Brasília obedecem às regras e normas estabelecidas como, as Leis de licitações, a $8.666 / 93$ e 10.520/02, ambas seguidas por todos os agentes compradores do serviço público.

Art. 1ํ Esta Lei estabelece normas gerais sobre licitações e contratos administrativos pertencente a obras, serviços, inclusive de publicidade, compras, alienações e locações no âmbito dos Poderes da União, dos Estados, do Distrito Federal de dos municípios.

Parágrafo único. Subordinam-se ao regime desta Lei, além dos órgãos da administração direta, os fundos especiais, as autarquias, as fundações públicas, as empresas públicas, as sociedades de economia mista e demais entidades controladas direta ou indiretamente pela União, Estados, Distrito Federal e Municípios. (BRASIL, 1993, p. 1).

Segundo Araújo (1976, p. 36) "existe um custo burocrático externo e outro interno. O processo administrativo de uma compra nos demonstrará a conveniência de conhecer a fundo o primeiro na sua caminhada normal e de respeitar o segundo, de acordo com as normas estabelecidas pelas empresas. É necessário, sobretudo, que todos os trâmites legais estejam perfeitamente resguardados por documentação escrita, incluindo-se anotações de conversações verbais, telefônicas etc.

Segundo Ballou (1993), a motivação da administração de materiais é satisfazer às necessidades de sistemas de operação, tais como uma linha de produção na manufatura ou um processo operacional de banco, hospital, etc. Essas necessidades provêm das curvas de demanda dos clientes, das atividades de promoção e dos programas e planos de distribuição física. Estas são convertidas nos programas e planos de produção ou operação. As operações da empresa são os clientes para o gerente de materiais da firma. Isto também é válido para organizações que compram com o propósito de revenda. A importância da boa administração de materiais pode ser mais bem apreciada quando bens necessários estão disponíveis no instante correto para atender às necessidades de produção ou operação.

As empresas públicas não são diferentes das empresas privadas, mas as regras são estabelecidas e aceitas partindo dos princípios estabelecidos pelas leis de licitações, submetendo as empresas fornecedoras de materiais, serviços e equipamentos a essas regras. 
Os agentes compradores nas repartições públicas, a partir do registro dos fornecedores inscritos, realizam uma espécie de levantamento que permite auxiliar as anotações indispensáveis à organização dos cadastros.

Os órgãos federais para executarem suas compras fazem uma série de exigências legais junto às empresas fornecedoras, devendo as mesmas estarem em situação de regularidade com a Receita Federal, Dívida ativa da União, INSS e FGTS e para concorrências de grandes vultos exige-se cadastramento em qualquer órgão federal e também, regularidade juntos aos órgãos estaduais.

Segundo Tachizawa (1997, p. 102), a organização flexível pressupõe uma estrutura interna ágil que assegure a continuidade das conquistas obtidas junto ao mercado. Enquanto o plano externo demanda que a organização tenha que ser eficaz, obtendo resultados econômicos favoráveis, internamente há necessidade de uma infra-estrutura administrativa que promova a convergência de suas ações de forma coerente com as mutações ambientais. Esta infra-estrutura administrativa (abrange, portanto, outros elementos como tecnologias aplicadas a produtos a processos e correlatos) e é constituída pelos recursos internos da organização, representados na forma de: estrutura organizacional, recursos humanos, sistemas e tecnologias da informação e processos sistêmicos.

O conhecimento cada vez mais, assume um papel central e importante na sociedade de hoje e do futuro. Os recursos econômicos básicos passam a contar, além do capital, dos recursos naturais e da mão-de-obra, com a contribuição dos conhecimentos necessários aos processos produtivos e de negócios.

Os processos evoluem e modificam ao longo de sua existência. São criados para um fim específico, sendo bastante claros e simples de acordo com a demanda do cliente. Sofrem refinamento com o passar do tempo. Adaptações e variações são feitas pelas pessoas que nele trabalham. Mudanças de planos organizacionais, fatores que vão levar o processo a um apropriado grau de institucionalização e amadurecimento que, podem acarretar em diminuição de eficácia, levando ao excesso de controle e colapso, gastando-se mais tempo e energia trabalhando 0 processo do que no seu resultado.(VILLELA, 2000).

Para isso, se faz necessário o acompanhamento constante dos processos no Serviço de Compras Nacionais, evitando a sua institucionalização para que ele não 
venha perder sua eficácia e conseqüentemente, gasto de tempo e energia para atingir sua finalidade.

Entendendo os processos organizacionais, a estrutura destes permitem a realização dos fluxos de trabalho através de processos até que o produto, ou serviço, esteja pronto e disponível ao consumidor. Para mudar a estrutura é necessário o conhecimento e deve-se entender o trabalho e o modo como este flui através dos processos da organização. $O$ entendimento dos processos é parte relevante da mudança planejada, pois nenhuma equipe de projeto pode mudar aquilo que não entende e nenhuma mudança será colocada em prática se não houver um porque para tal. (VILLELA, 2000).

As mudanças ocorridas nos dias atuais no ambiente global obrigaram as diversas empresas a se depararem com o aumento da competição, obrigando-as a buscar vantagens competitivas, eficiência e lucratividade para diferenciarem-se das demais. O advento da tecnologia, em especial da tecnologia de informação, tem acarretado um aumento nas expectativas dos cidadãos por serviços e informações rápidas e confiáveis. Assim a principal característica deste novo cenário econômico é o desenvolvimento das capacidades de conexão entre pessoas, empresas e comunidades, impactando intensamente a forma que os negócios são gerenciados.

Para Obolensky (1996), a reengenharia de negócios é aplicada na empresa para modificar os controles e os processos internos de uma hierarquia tradicional vertical e funcional para uma estrutura plana, horizontal, multifuncional, baseada no trabalho de equipe que focalize o processo de satisfazer seus clientes.

A incidência desse fenômeno não só nas empresas privadas, como também no governo, por meio do emprego da tecnologia da informação como ferramenta para a melhoria da qualidade dos serviços públicos, através do governo eletrônico. Tem sido observado, portanto, uma crescente preocupação dos órgãos públicos em tornar mínimo o desperdício, ineficiência, obsolescência e falta de transparência. Através do E-Gov o Estado tenta obter padrões de rapidez e diminuição de custos, da mesma forma que a iniciativa privada.

Segundo Wozorek, Tamos e Resende (2005), o E-Gov pode ser entendido como a aplicação dos recursos das Tecnologias de Informação e comunicação TIC's na gestão e na política das organizações públicas, superando a simples 
prestação de serviços aos cidadãos através dos meios eletrônicos. O E-Gov reflete, portanto, um novo modelo de relacionamento entre governo, cidadãos e fornecedores, no contexto da economia digital.

Através do Decreto Presidencial de 3 de abril de 2000, criado por um Grupo de Trabalho Interministerial, iniciou o marco do governo eletrônico no Brasil. Desde então o Governo brasileiro vem implementando um conjunto de projetos e iniciativas de Governo Eletrônico a fim de assimilar novas concepções, tecnológicas e práticas de gestão (MEDEIROS; GUIMARÃES, 2006).

Dentre as práticas de Governo Eletrônico no Brasil, é evidenciada a instituição da modalidade de Pregão Eletrônico nos processos de licitação da Administração Pública Brasileira estabelecida pelo Decreto 5.504 de 5 de agosto de 2005. Segundo este decreto, a Administração Pública Federal (Compreendidos aos três Poderes) deve-se utilizar preferencialmente o pregão na forma eletrônica, nas aquisições e nas contratações de bens e serviços comuns no âmbito da administração Pública (BRASIL, 2005).

O Pregão eletrônico ocorre através do portal de compras públicas do Governo Federal e funciona como um leilão reverso no qual a disputa ocorre com o envio sucessivo de lances decrescentes pela internet. Esta modalidade de compras tem obtido sucesso desde sua implantação e vem alcançando resultados positivos, principalmente no que se refere a redução de custos. No primeiro semestre de 2007, o Governo Federal economizou $\mathrm{R} \$ 597$ milhões $(12,7 \%)$ do preço de tudo que adquiriu com o uso do pregão eletrônico nas compras públicas realizadas. (COMPASTENT, 2007).

Entretanto, a questão realmente importante é se as organizações também se tornarão mais inteligentes. Para que isto ocorra, serão fundamentais os tipos de habilidades de aprendizagem construídas dentro das organizações, sendo requerido que estas sejam mais do que obrigatoriamente competentes na aprendizagem de circuito único (que se apóia em uma habilidade de detectar e corrigir o erro com relação a um dado conjunto de normas operacionais), mas também possuir habilidades em termos de aprendizagem de circuito duplo (que depende de ser capaz de olhar de forma multifacetada uma dada situação, questionando a relevância das normas em funcionamento), conforme defendido por (MORGAN, 1995). 
Para Davenport (1954), diante da intensa concorrência e outras pressões econômicas que recai sobre as grandes organizações na década de 1990, as iniciativas de melhoria de qualidade e de melhoria contínua e paulatina de processos, embora sejam essenciais, já não bastarão. As metas de uma melhoria anual de 5 ou $10 \%$ em todos os processos empresariais devem dar lugar aos esforços para atingir níveis de melhoria de $50 \%, 100 \%$, ou até mais, nuns poucos processos-chave. As empresas têm de buscar hoje não níveis fracionais de melhoria, mas sim níveis multiplicativos - 10x e não 10\%. Esses níveis radicais de transformação exigem instrumentos novos e poderosos que facilitarão a reconfiguração fundamental do trabalho.

Portanto, o diagnóstico do fluxo de informações oriundo das comunicações entre os elos da cadeia cliente-fornecedor, constitui etapa essencial para reconhecer se o mesmo está operando de forma eficiente.

A melhoria dos processos organizacionais é normalmente gerada a partir da melhoria dos processos de fluxo de materiais e informações. À medida que se implementa melhorias no fluxo de informações, automaticamente promove-se melhoria no processo como um todo e ter este fluxo registrado certamente auxilia na visualização das deficiências de funcionamento e conseqüentemente nas alterações possíveis de se implementar tanto para os processos como para o sistema de comunicação. 


\section{Objetivo Geral}

O objetivo desse trabalho é propor a elaboração de um processo uniformizado de aquisição de compras de serviços e materiais adequado às necessidades da UnB

\subsection{Objetivos Específicos}

- Analisar e modelar o processo de compras da UnB de forma a alcançar um modelo Unificado.

- Analise comparativa com outros modelos de compras em Instituição Federais de Ensino Superior (IFES).

\subsection{Justificativas}

Para Justificar essa proposta foi feita uma pesquisa junto aos arquivos do Serviço de compras Nacionais (SCN) vinculado a Diretoria de Recursos Materiais (DRM) da Universidade de Brasília, UnB e também por meio eletrônico em sua página na Internet, no período de novembro de 2008 a março de 2009, devidamente autorizada pelo Chefe do Serviço de Compras Nacionais, visando conhecer as etapas do processo de compras e documentos que o geram e que o compõem para a elaboração de um modelo uniformizado de aquisição de compras de serviços e materiais, baseado em processos organizacionais.

Para melhor compreensão e balizamento do processo de Compras Da Universidade de Brasília, foi pesquisada também por meio eletrônico em outras Instituições de Ensino Superior do Brasil em suas páginas na Internet comparando seus processos de compras com os da Universidade de Brasília (UnB), no mesmo período citado acima.

Os processos evoluem e modificam ao longo de sua existência. São criados para um fim específico, sendo bastante claros e simples de acordo com a demanda do cliente. Sofrem refinamento com o passar do tempo. Adaptações e variações são feitas pelas pessoas que nele trabalham. Mudança de planos organizacionais, fatores que vão levar o processo a um apropriado grau de institucionalização e amadurecimento que, podem acarretar a diminuição da eficácia, levando ao excesso de controle e colapso, gastando-se mais tempo e energia trabalhando o processo do que no seu resultado. VILLELA, 2000) 


\section{REFERENCIAL TEÓRICO}

\subsection{Processos organizacionais e gestão por processos: conceituação}

"O processo consiste em um conceito fundamental no projeto dos meios pelos quais uma empresa pretende produzir e entregar seus produtos e serviços aos seus clientes". (GONÇALVES, 2000, p. 9).

Gonçalves (2000) apud Monteiro (2003, p. 10) explicita que a compreensão dos processos nas empresas implica na identificação dos variados aspectos desses processos, como "o fluxo (volume por unidade de tempo), seqüência das atividades, esperas e duração do ciclo, dados e informações, pessoas envolvidas, relações e dependências entre as partes comprometidas no funcionamento do processo".

Oliveira (1996) apud Monteiro (2003) aborda que processo constitui-se num conjunto de tarefas ordenadas que possuem relação lógica entre si, com o objetivo de satisfazer e superar as necessidades e expectativas dos clientes externos e internos de uma organização.

Para Adair e Murray (1996) apud Monteiro (2003), o processo consiste num conjunto de atividades realizadas com o objetivo de apresentação de um resultado identificável, podendo ser um bem, um serviço, dados, informações ou conhecimentos, que são voltados a um cliente, interno ou externo, o qual é capaz, então, de avaliar e definir este resultado.

Já Gonçalves (2000) apud Monteiro (2003, p. 14) descreve processo como

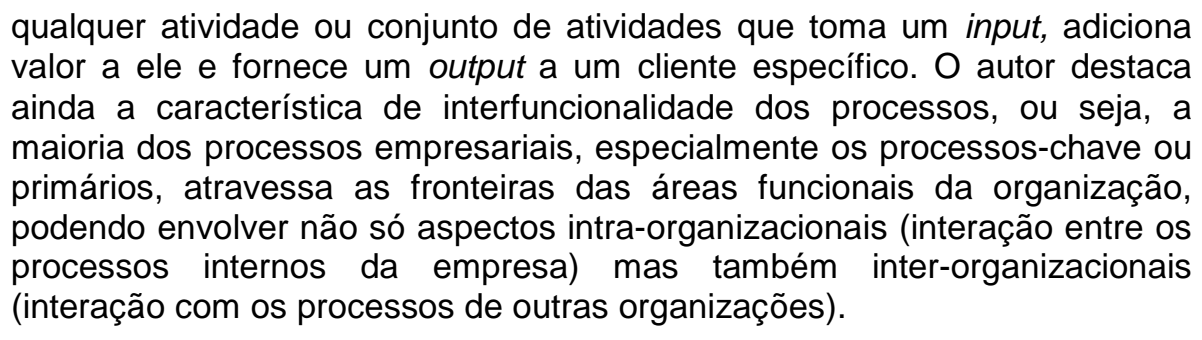

Gonçalves (2000) apud Monteiro (2003) destaca que o pensamento de processo como um fluxo de trabalho com inputs e outputs claramente fixados e atividades discretas que possuem uma seqüência e dependem umas das outras numa ordem clara vem da tradição da engenharia. Nessa abordagem, os processos também têm começo e fim bem estabelecidos. 
Entretanto, como Gonçalves (2000) relembra, o fluxo de trabalho trata de apenas um dos tipos de processo empresarial, talvez aquele em que as tarefas são mais interdependentes e realizadas numa sucessão específica. Essa definição restrita, então, não abrange os processos que não têm início e fim bem definidos ou cujo fluxo não é bem claro.

Cinco modelos de processos empresariais formam um exemplo que abrange desde o mais concreto modelo, baseado no fluxo de materiais, até o modelo mais abstrato, que se refere à modificação de estados de um sistema. O Quadro 1 traz as principais características desses modelos e fornece exemplos. (GONÇALVES, 2000).

\begin{tabular}{|l|l|l|}
\hline \multicolumn{1}{|c|}{ Processo como } & \multicolumn{1}{|c|}{ Exemplo } & \multicolumn{1}{c|}{ Características } \\
\hline Fluxo de material & $\begin{array}{l}\text { Processos de fabricação } \\
\text { industrial }\end{array}$ & $\begin{array}{l}\text { - inputs e outputs claros } \\
\text { - atividades discretas } \\
\text { - fluxo observável } \\
\text { - desenvolvimento linear } \\
\text { - seqüência de atividades }\end{array}$ \\
\hline Fluxo de trabalho & $\begin{array}{l}\text { Desenvolvimento de produto } \\
\text { Recrutamento e contratação } \\
\text { de pessoal }\end{array}$ & $\begin{array}{l}\text { - atividades dinal claros } \\
\text { - seqüência de atividades }\end{array}$ \\
\hline Série de etapas & $\begin{array}{l}\text { Modernização do parque } \\
\text { industrial da empresa } \\
\text { Redesenho de um processo } \\
\text { Aquisição de outra empresa }\end{array}$ & $\begin{array}{l}\text { - caminhos alternativos para o } \\
\text { resultado } \\
\text { - nenhum fluxo perceptível } \\
\text { - conexão entre atividades }\end{array}$ \\
\hline Atividades coordenadas & $\begin{array}{l}\text { Desenvolvimento gerencial } \\
\text { Negociação salarial }\end{array}$ & $\begin{array}{l}\text { - sem seqüência obrigatória } \\
\text { - nenhum fluxo perceptível }\end{array}$ \\
\hline Mudança de estados & $\begin{array}{l}\text { Diversificação de negócios } \\
\text { Mudança cultural da empresa }\end{array}$ & $\begin{array}{l}\text { - evolução perceptível por meio de } \\
\text { indícios } \\
\text { - fraca conexão entre atividades } \\
\text { - durações apenas previstas } \\
\text { - baixo nível de controle possível }\end{array}$ \\
\hline
\end{tabular}

Quadro 1 - Espectro dos principais modelos de processos.

Fonte: Gonçalves (2000, p. 7).

Deste modo, como conclui Morris e Brandon (1994) apud Gonçalves (2000) os processos organizacionais muitas vezes não são formados de atividades claramente estabelecidas em relação ao conteúdo, duração e consumo de recursos definidos, nem precisam ser consistentes ou realizados numa seqüência específica.

O processo institucional também pode ser definido como trabalho que, sendo usual, atinge algum aspecto da capacitação da empresa (organizational capability), e possa ser realizado de diversas formas distintas com resultados diferentes em termos da contribuição que pode gerar com relação a custo, valor, serviço ou qualidade e envolva a articulação de esforços para a sua realização (Keen, 1997 apud Gonçalves, 2000). 
Sob um olhar diferente,

os processos empresariais são atividades coordenadas que envolvem pessoas, procedimentos e tecnologia. Na verdade, os processos em geral, e em particular, de negócio representam uma nova abordagem à coordenação de atividades ao longo da empresa. (MALHORTA, 1998 apud GONÇALVES, 2000, p. 8).

Cameron at al.., 1995 apud Gonçalves (2000) consideram que o processo consiste na maneira particular de realizar um determinado conjunto de atividades, sob o ponto de vista de estudiosos em análise do trabalho humano. Assim, a definição inclui não apenas as tarefas a serem realizadas, mas também o número de empregados, a distribuição do trabalho entre eles, a tecnologia empregada, os indicadores de eficiência e os resultados esperados. Segundo Lpinack e Stamps (1997) apud Gonçalves (2000) os processos podem ser compreendidos como o modo pelo qual as coisas são feitas na empresa e a "maneira mais abrangente de definir processo empresarial é como produzir alguma coisa". (Malone at al.., 1997 apud Gonçalves, 2000, p. 9).

Porém, algumas vezes, as tarefas essenciais (aquelas que são essenciais para que sejam atingidos os objetivos da empresa) podem ser denominadas processos. "Elas envolvem um conjunto de atividades operacionais, diversos níveis organizacionais e práticas gerenciais". Resumidamente, elas constituem-se nos processos que necessitam ser executados para que a corporação exista (Bennis e Mische, 1995 apud Gonçalves, 2000, p. 9). O Quadro 2 ilustra uma série de sistemas empresariais selecionados.

\begin{tabular}{|l|l|}
\hline \multicolumn{1}{|c|}{ Família de processos } & \multicolumn{1}{c|}{ Processos selecionados } \\
\hline Administração geral & - Definição de visão \\
& - Desenvolvimento de lideranças \\
& - Gerência de contas \\
& - Comunicações internas \\
& - Projeções econômicas e setoriais \\
\hline Manufatura & - Gestão da qualidade \\
& - Planejamento da capacidade \\
& - Planejamento da produção \\
& - Controle de estoques \\
& - Suprimentos \\
& - Distribuição \\
\hline Marketing & - Definição de preços \\
& - Gestão de canal \\
& - Introdução de produtos \\
& - Pesquisa de marketing \\
& - Planejamento de propaganda \\
\hline Educacionais & - Desenvolvimento de habilidades \\
& - Educação do consumidor \\
& - Desenvolvimento gerencial \\
\hline
\end{tabular}




\begin{tabular}{|c|c|}
\hline Família de processos & Processos selecionados \\
\hline Desenvolvimento de tecnologia & $\begin{array}{l}\text { - Pesquisa e desenho } \\
\text { - Avaliação de tecnologia } \\
\text { - Seleção de novos produtos } \\
\text { - Definição de padrões } \\
\text { - Gestão de projetos } \\
\text { - Teste de protótipos }\end{array}$ \\
\hline Financeiros & $\begin{array}{l}\text { - Gestão de orçamento empresarial } \\
\text { - Planejamento de investimentos } \\
\text { - Acompanhamento do desempenho } \\
\text { - Gestão de crédito de clientes } \\
\text { - Gestão de caixa } \\
\text { - Desmobilização de ativos }\end{array}$ \\
\hline Organizacionais & $\begin{array}{l}\text { - Planejamento de recursos humanos } \\
\text { - Programa de demissão voluntária } \\
\text { - Recrutamento e seleção } \\
\text { - Avaliação de desempenho } \\
\text { - Promoção }\end{array}$ \\
\hline Legais & $\begin{array}{l}\text { - Regulamentação } \\
\text { - Registro e controle de patentes }\end{array}$ \\
\hline De aliança & $\begin{array}{l}\text { - Gestão de parcerias } \\
\text { - Joint ventures }\end{array}$ \\
\hline Comerciais & $\begin{array}{l}\text { - Incentivos e recompensas para força de } \\
\text { vendas } \\
\text { - Marketing direto } \\
\text { - Gestão de filiais }\end{array}$ \\
\hline Gerenciamento de Linha de produto & $\begin{array}{l}\text { - Gestão de produto específico } \\
\text { - Consultoria } \\
\text { - Outsourcing }\end{array}$ \\
\hline De suporte ao cliente & $\begin{array}{l}\text { - Suporte técnico } \\
\text { - Gestão de instalações } \\
\text { - Garantia } \\
\text { - Reparo }\end{array}$ \\
\hline
\end{tabular}

Quadro 2 - Exemplos de processos empresariais selecionados.

Fonte: Adaptado de Peter Keen (1997) apud Gonçalves (2000, p. 9).

Assim, pode se perceber que a definição de processo pela descrição da transformação de inputs em outputs de valor não supre a necessidade de se especificar o tema que interessa. Pois um processo típico também abrange endpoints, transformações, feedback e repetibilidade. "As modificações ocorridas num processo podem ser físicas, de localização e transacionais (transformação de itens não tangíveis)". (GONÇALVES, 2000, p. 10).

A aplicação de todas essas qualidades na definição do que é processo possibilita garantir condições mais apropriadas e relevantes para a sua análise e gestão. (GONÇALVES, 2000).

A importância dos processos essenciais na gestão das empresas vai da identificação e definição desses processos, passa pelo aperfeiçoamento de tais processos, pela priorização deles na gestão da empresa com um todo e chega até a redefinição da estrutura organizacional e do funcionamento da empresa em função dos seus processos básicos. (GONÇALVES, 2000, p.12). 
Gonçalves (1997) apud Gonçalves (2000) aborda que o funcionamento das organizações segundo a lógica dos processos acarreta na adoção de novas formas de trabalho e de gerenciamento do trabalho. Desta maneira, a gestão por processos organizacionais diverge da gestão por funções tradicional uma vez que ela emprega objetivos externos, seus trabalhadores e recursos são agrupados para produzir um trabalho completo e a informação é encaminhada diretamente para onde é necessária, sem o filtro e passagem pela hierarquia (Stewart, 1992 apud Gonçalves, 2000). O sucesso, então, da gestão por processos está relacionado à energia despendida para minimizar a subdivisão dos processos empresariais.

A gestão por processos apóia-se no emprego de um sistema de medidas baseado em processos (process centered measurement system). Esses sistemas dão ênfase às variáveis e medidas referentes aos processos, e não às unidades verticais. As metas adotadas pela empresa, por exemplo, são as dos processos, e não aquelas adotadas tradicionalmente pelas áreas funcionais. (GONÇALVES, 2000, p. 13).

"A essência da gestão por processo, então, é fundamentada na coordenação das atividades realizadas na empresa, em particular aquelas executadas por variadas equipes de diversas áreas". (GONÇALVES, 2000, p. 13).

\subsection{A reengenharia de processos como instrumento de melhoria de desempenho organizacional}

O impulso para melhoria do desempenho organizacional demonstra uma preocupação constante no século $X X$, conjuntamente às modificações em dimensão planetária que exigem empresas proativas e flexíveis, como requisitos essenciais à sobrevivência e ao sucesso empresarial. (CARAVANTES, 1997).

Estas mudanças geram buscas de novas formas de aperfeiçoamento da gestão de empresas com o objetivo de melhorar seu desempenho, o que acarretou em diversas abordagens em curso nas organizações. (CARAVANTES, 1997).

Assim, Caravantes (1997) salienta que a reengenharia se moldou não apenas como um enfoque empresarial temporário, mas como uma filosofia de sobrevivência.

Segundo Davenport (1994), a abordagem, então, inovadora, necessária ao desempenho comercial deveria abranger tanto a forma de ver e estruturar a atividade, como também a maneira de agregá-la mais valor. As atividades institucionais deveriam ser vistas não de acordo com suas funções, departamentos ou produtos, mas de seus processos-chave. $O$ que se traduz em replanejamento 
destes processos do início ao fim, "com o emprego de tecnologias inovadoras e recursos organizacionais disponíveis". (DAVENPORT, 1994, p. 1).

Trata-se, portanto, da reengenharia de processos, que combina a adoção de uma visão processual da atividade com a aplicação da reengenharia aos processos-chave. O que há de novo e característico nessa combinação é o seu enorme potencial de ajuda de que qualquer organização precisa para obter reduções importantes no custo ou no tempo de realização do processo, ou importantes melhorias de qualidade, flexibilidade, níveis de atendimento ou demais objetivos empresariais. (DAVENPORT, 1994, p. 2).

Pode-se, desta forma, definir a reengenharia, de acordo com Hammer e Champy (1994) apud Caravantes (1997, p. 37), como o repensar primordial e a reestruturação drástica dos processos empresariais "que almejam alcançar melhorias impactantes em indicadores críticos de desempenho, como custos, qualidade, atendimento e velocidade".

Davenport (1994, p. 12) ainda define a reengenharia "como a adoção de alguma coisa inovadora, em que se acredita que a intenção do emprego de algo inovador num processo seja estimular uma mudança importante, significativa e radical. Deste modo, "a reengenharia combina uma estrutura para realização de trabalho com uma preocupação com resultados viáveis e drásticos".

Para Lowenthal (1994) apud Caravantes (1997, p. 38),

a reengenharia consiste no repensar e no redesenhar dos processos e da estrutura organizacional, focando os valores centrais da organização a fim de atingir melhorias importantes como: redução de custos, aumento da qualidade dos produtos e serviços, aumento da participação no mercado e lucros.

A reengenharia reestrutura a maneira como o trabalho é desenvolvido na organização, não tenta aperfeiçoar processos já existentes. Ela modifica processos, envolvendo seu redesenhar, o que normalmente acarreta mudança no sistema e na infra-estrutura, com o objetivo de se tirar vantagens do potencial da instituição e de seus principais valores. (CARAVANTES, 1997).

Caravantes (1997, p. 40) afirma que, "a reengenharia pode contribuir, então, para intensificar nas empresas, o planejamento e o controle dos prazos e custos, conduzindo com mais rapidez os programas de qualidade".

Davenport (1994, p. 12) faz ainda uma distinção entre melhoria de processos e reengenharia de processos, descrevendo que, o primeiro almeja um nível inferior de modificação, pois significa a realização de um processo com eficácia e eficiência 
maior, enquanto que o segundo visa a realização do mesmo processo de forma extremamente nova. Algumas características presentes nos dois modos de estratégia organizacional encontram-se exemplificadas no quadro a seguir:

\begin{tabular}{|l|c|c|}
\hline & Melhoria & Reengenharia \\
\hline Nível de mudança & Gradual & Radical \\
\hline Ponto de partida & Processo existente & Estaca zero \\
\hline Freqüência de mudança & De uma vez/ contínua & De uma vez \\
\hline Tempo necessário & Curto & Longo \\
\hline Participação & De baixo para cima & De cima para baixo \\
\hline Âmbito típico & Limitado, dentro de funções & Amplo, interfuncional \\
\hline Risco & Moderado & Alto \\
\hline Habilitador principal & Controle estatístico & Tecnologia da informação \\
\hline Tipo de mudança & Cultural & Cultural/estrutural \\
\hline
\end{tabular}

Quadro 3 - Melhoria de Processos versus Reengenharia de Processos.

Fonte: Davenport (1994, p. 13)

Kaplan e Norton (1997) apud Monteiro (2003), abordam que as organizações modernas funcionam com processos interfuncionais e destacam a melhoria constante de produtos e processos como garantia de sucesso empresarial.

Monteiro (2003) enfatiza que a organização centrada em tarefas deve dar lugar a organização orientada para os processos. Conforme ilustrado nas figura $1 \mathrm{e}$ 2.

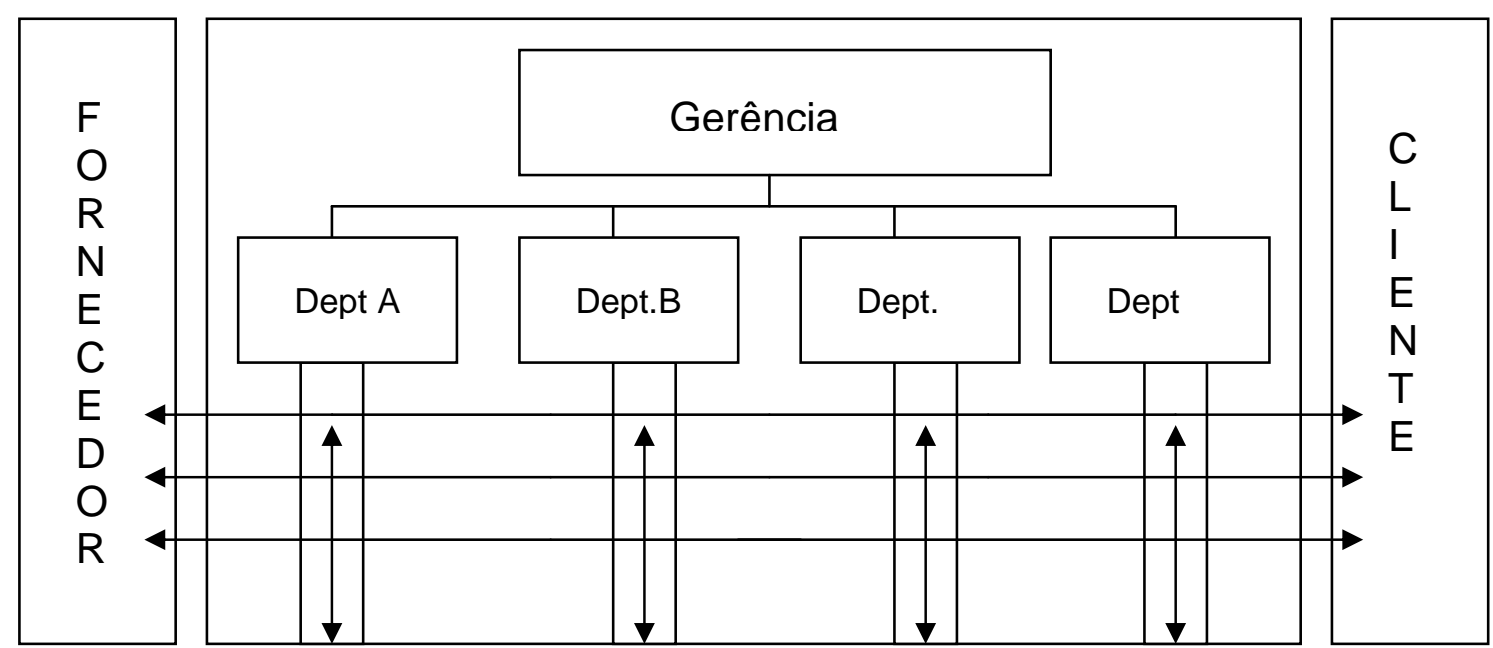

Figura 1 - A organização tradicional, centrada em tarefas.

Fonte: Adaptado de Slack at al. (1999) apud Monteiro (2003, p. 16) 


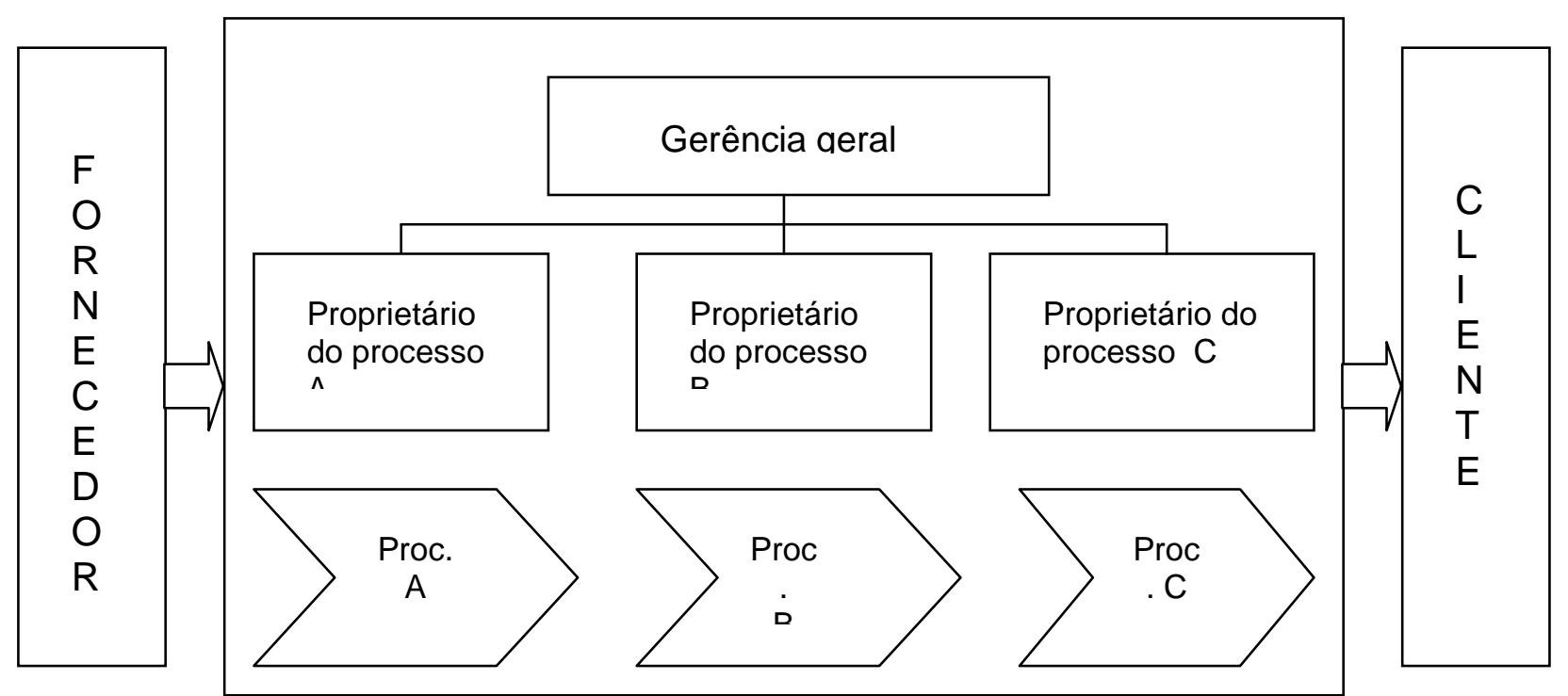

Figura 2 - A organização orientada para os Processos.

Fonte: Adaptado de Slack at al. (1999) apud Monteiro (2003, p. 17)

\begin{tabular}{|l|l|l|}
\hline \multicolumn{1}{|c|}{ Características } & \multicolumn{1}{|c|}{ Organização tradicional } & $\begin{array}{l}\text { Organização orientada para os } \\
\text { Processos }\end{array}$ \\
\hline Foco & Na organização & No cliente (externo/ interno) \\
\hline Responsabilidade & Tarefas individuais & Processo inteiro/resultados \\
\hline Estrutura & Vertical/ departamentalização & $\begin{array}{l}\text { Horizontal/ processos essenciais/ } \\
\text { proprietário do processo }\end{array}$ \\
\hline $\begin{array}{l}\text { Integração (interna/empresa } \\
\text { e ambiente externo) }\end{array}$ & Fraca & Forte \\
\hline Equipes & Funcionais/dirigidas & Multifuncionais/ auto-dirigidas \\
\hline Cultura & $\begin{array}{l}\text { Resistência à } \\
\text { mudança/autocracia/ } \\
\text { desconfiança/individualismo }\end{array}$ & $\begin{array}{l}\text { Aprimoramento contínuo/ } \\
\text { confiança/ colaboração/ eficiência }\end{array}$ \\
\hline
\end{tabular}

Quadro 4 - Organização tradicional x Organização orientada para os Processos.

Fonte: Adaptado de Gonçalves (2002) apud Monteiro (2003, p. 17)

Os processos, desta maneira, são descritos para Graham e LeBaron (1994) apud Gonçalves (2000, p. 7), como "todo trabalho importante realizado nas empresas". "Um processo consiste num grupo de atividades realizadas numa seqüência lógica com o objetivo de produzir um bem ou um serviço que tem valor para um grupo específico de clientes" (Hammer e Champy, 1994 apud Gonçalves, 2000).

Gonçalves (2000, p. 13) associa o conceito de processo à idéia de cadeia de valor, "como uma coleção de atividades que envolvem a empresa de ponta a ponta com o propósito de entregar um resultado a um cliente ou usuário final".

As empresas necessitam estar aptas sobre seu potencial de centralização das prioridades, as ações e os recursos nos seus processos, o que se torna possível 
através da reengenharia, que visa a reestruturação e otimização no emprego de recursos e custos.

Coulson-Thomas (1996) apud Monteiro (2003, p. 17-8) definem que as organizações devem possuir habilitações para serem orientadas em processos, como:

a) Orientar-se pelo cliente, fornecendo produtos e serviços que satisfaçam as suas reais necessidades;

b) Identificar quais são os processos do negócio e direcionar esforços àqueles que podem agregar significativo valor para o cliente e gerar vantagem competitiva;

c) Eliminar as fronteiras interdepartamentais, de modo que as atividades sejam executadas de acordo com um modelo horizontal baseado em processos e não em tarefas especializadas executadas por departamentos estanques. Levar em conta que os processos de uma organização interagem tanto interna quanto externamente;

d) Definir indicadores para gerenciar o desempenho dos processos;

e) Definir equipes multifuncionais para cuidarem do processo do início ao fim, com autonomia para tomada de decisões e responsabilidade pelos resultados;

f) Estimular a comunicação interpessoal e o aprendizado e recompensar o desempenho;

g) Obter o comprometimento de todos com a nova orientação, em especial da alta administração.

Davenport (1994) apud Monteiro (2003, p. 42-6) aponta os seguintes habilitadores da reengenharia de processos:

a) Alinhamento com a estratégia: pois, de acordo com o autor, a reengenharia de processos deve estar estreitamente ligada à estratégia da organização. Devendo então, estabelecer quais processos serão reestruturados, e as metas de desempenhos que deverão ser atingidas.

b) Metodologia: o autor descreve que dificilmente a reengenharia de processos obterá sucesso sem um direcionamento metodológico que sistematize e otimize os esforços a serem alocados em cada proposta de 
reengenharia. Assim, para Davenport (1994) a reengenharia de processos pode ser implementada conforme as etapas abaixo:

- Identificação dos processos para reengenharia: nessa fase procura-se identificar quais os processos que a organização possui, para que se possa priorizar os que serão candidatos à reengenharia

- Identificação das ferramentas de mudança: Davenport, então, salienta que nesta etapa há a identificação dos habilitadores organizacionais e de recursos humanos que serão utilizados, assim como o gerenciamento de mudança.

- Definição dos objetivos e características do processo: esta etapa possui o ideal de se alinhar o processo à estratégia organizacional, como as metas de desempenho que se pretende atingir (custo, qualidade, velocidade, flexibilidade e confiabilidade), além de especificações que devem estar presentes na operação do processo, como a tecnologia a ser utilizada, gerenciamento do processo por equipes multifuncionais e autogeridas, agrupamento das atividades do processo em um único local.

- Compreensão do processo existente: neste momento busca-se entender o funcionamento do processo, além das oportunidades de melhoria, tendo como base os objetivos de desempenho e os atributos especificados para o novo processo.

- Projeto e protótipo do novo projeto: desenvolvimento e implementação do novo processo.

c) Habilitadores organizacionais e de recursos humanos: abrange a criação de estruturas organizacionais focadas nos processo empresariais e à implementação de equipes interfuncionais responsáveis pelo redesenho do processo, com conseqüente capacitação destes recursos.

d) Tecnologia da informação (TI): Davenport enfatiza a importância da tecnologia de informação na reengenharia de processos devido às vantagens que proporciona, como: automacional, dispensando-se a mãode-obra para realização do processo; informacional, pois permite a obtenção de informações a respeito do processo para posterior avaliação do desempenho; seqüencial: pois possibilita modificação de um processo de execução em série para execução em paralelo; controle: pois a 
tecnologia de informação permite o acesso à informações de cada etapa do processo, o que viabiliza ações corretivas mais ágeis na execução do processo; geográfico: pois fornece meios para que as empresas superem as distâncias geográficas e alinhe processos; integrativo: pois possibilita que diferentes atividades sejam agrupadas e integradas na mesma estação de trabalho, reduzindo-se o tempo; intelectual: pois 0 conhecimento produzido pela empresa pode ser armazenado em bancos de dados e acessado pelas diversas partes interessadas; desintermediação: devido a maior aproximação entre fornecedores e clientes.

\subsection{Tecnologia da informação e Gestão do conhecimento na reengenharia de processos organizacionais}

Segundo Caravantes (1997), a tecnologia da informação desempenha um papel primordial na Reengenharia nas organizações. Pois ela incorpora qualquer esforço de Reengenharia, sendo um capacitador fundamental, por permitir às empresas a reengenharia de processos. Ela pode dar apoio a quase todas as etapas de criação e implementação de novos processos, assim como à formação de sistemas de ajuda, apoio aos processos.

Em relatório sobre as repercussões da TI na reengenharia, o presidente da Academia Nacional de Administração Pública (National Academy of Public Administration) (1994) apud Caravantes (1997, p. 52-3), diz que:

informação é o pivô para a vitalidade e a produtividade dos serviços
governamentais e para a competitividade econômica da nação. A questão é,
se podemos utilizar a tecnologia da informação de um modo eficaz a fim de
capacitar o governo, o setor privado, bem como os cidadãos. A
complexidade do mundo atual exige que ambos os setores público e privado
não só aprendam a gerenciar (dominar) esta ferramenta, como trabalhar
cooperativamente para maximizar os benefícios à nação.

Davenport (1994) apud Caravantes (1997, p. 53) também reforça esta característica de implementador da mudança de processos. Assim, segundo o mesmo autor,

a tecnologia de informação é ao mesmo tempo um habilitador e um processo que exige a tecnologia da informação para realizar a mudança radical, e para usar as capacidades da tecnologia da informação de maneira interfuncional, impulsionada pelo desempenho, é necessária uma visão de processo. 
Desta maneira, Caravantes (1997) destaca ainda, que o verdadeiro poder da tecnologia da informação, não se encontra no aprimoramento de antigos processos, mas está na permissão do rompimento com regras do passado e a criação de novas regras de trabalho, ou seja, na prática da reengenharia.

Neste sentido,

a Gestão do Conhecimento consiste num conjunto de procedimentos, infraestrutura tecnológica, práticas e ferramentas para possibilitar a efetiva aquisição, organização e distribuição de informações relevantes, para as pessoas certas no tempo certo, de modo a capacitá-las a contribuir na realização dos objetivos do negócio através de ações eficazes. (SIVAN, 1998 apud SANTOS e CERANTE, 2000).

A gestão do conhecimento, então, encontra-se intimamente vinculada à reengenharia de processos na medida em que possibilita o gerenciamento de recursos de informação, como banco de dados, documentos, políticas da organização.

Esta abordagem trata, deste modo, de algumas características importantes para compreensão do que vem a ser esta gestão, como o conceito de memória organizacional, que para (Concklin, 1996 (apud Santos e Cerante 2000), p. 19), seria "um amplo repositório de todo tipo de registro na organização, ou seja, que possa apresentar alguma relevância para a organização". O de aprendizado organizacional, que pode ser compreendido segundo Santos e Cerante (2000, p. 20), como

\begin{abstract}
o esforço de se desenvolver dois tipos de atividades dentro da empresa: aquelas voltadas para o aspecto de adaptação e portanto de caráter mais passivo, que buscam obter conhecimento com base na aplicação de regras pré-existentes, ou ainda aquelas que permitem "quebrar" as regras para o estabelecimento de novas premissas com enfoque gerativo e portanto mais atuante e ativo. A interação entre estes dois aspectos do Aprendizado Organizacional, adaptativo e gerativo, permite que se amplie a capacidade de criação do conhecimento dentro de uma empresa.
\end{abstract}

O de tecnologia da informação, que é esclarecido por Davenport (1998) apud Santos e Cerante (2000) em que se coloca o homem no centro da organização, com o objetivo de se pensar o ambiente informacional em sua totalidade e "abranger aspectos como a cultura da organização, além de seus valores e crenças a respeito da informação". Trata, então, das rotinas e processos de trabalho e o aspecto comportamental, ou seja, a maneira como a informação é utilizada na empresa, além das políticas que facilitam ou dificultam esta utilização. 
E o de inteligência competitiva, definido por Santos e Cerante, 2000, p. 20, como

todo o tipo de solução que transforme o sistema tradicional de armazenamento e manipulação de dados contidos nas organizações, em conjuntos de ferramentas de informação que sejam capazes de prover suporte à evolução e crescimento de seus negócios.

A associação da gestão do conhecimento às tecnologias de informação encontram-se, então, de acordo com Noronha (2000) apud Andrade (2002), nos fluxos da informação na corporação, que tendem a tornar-se mais efetivos em razão do aumento da capacidade de coletar, estocar, processar e transferir informações, o que permite a aquisição de uma maior velocidade na comunicação, diminuição no prazo das respostas às variações dos ambientes interno e externo, melhoria na tomada de decisão, isto é, um aumento da eficiência organizacional em diversos aspectos.

Para Ramos (1996) apud Andrade (2002, p. 50), "a consistência, a repetibilidade e a rapidez na execução de uma atividade são diretamente proporcionais às ferramentas de trabalho disponíveis", assim, é possível concluir que a elevação da eficiência e, conseqüentemente, a obtenção de pontos de produtividade podem ser obtidos pelo uso das tecnologias de informação aos fluxos de informação.

"Para a conquista e manutenção da competitividade, as empresas buscam cada vez mais a sua eficiência e a tecnologia tem sido uma grande aliada neste processo". (ANDRADE, 2002, p. 50).

Afirma ainda Furlan, 1994 apud Andrade, 2002, p. 54, que

a Tecnologia da Informação deve ser vista não apenas como uma
ferramenta para a automatização ou desenho de processos, mas,
principalmente, como uma ferramenta que pode auxiliar na reformulação do
modo como o negócio opera, na redução do tempo de resposta, num
melhor balanceamento de recursos e na redução de custos.

Andrade (2002, p. 57), reforça que a agilidade constitui-se num dos principais requisitos para a competitividade/inteligência competitiva. "'Descomplicar" a decisão, facilitar o fluxo de informação, aumentar a autonomia dos envolvidos e dar maior rapidez à implantação das idéias e à resposta ao cliente e ao parceiro de negócio faz a grande diferença". 


\subsection{Administração pública e a necessidade de racionalização dos custos: Pregão eletrônico}

Os processos de assimilação de tecnologia da informação e comunicação (TIC) têm causado impactos profundos na vida das organizações. Entre outros efeitos, têm proporcionado o aparecimento de novos arranjos organizacionais, com destaque para as organizações virtuais. Neste contexto encontra-se a noção de governo eletrônico (e-gov), que se constitui no uso, pelos governos, das novas tecnologias da informação e comunicação na prestação de serviços e informações para cidadãos, fornecedores e servidores. (MENEZES, 2005).

Menezes, Silva e Linhares (2007) destacam que a moderna tecnologia da informação também provocou grandes transformações na administração dos recursos logísticos de todas as organizações. A interdependência das finalidades, analisada por meio de sistemas integrados de gestão, provocou a renovação das funções exercidas pelas atividades logísticas, entre as quais se distingue a função compras, pois esta perdeu o foco operacional, assumindo uma perspectiva estratégica, com grande ênfase no processo de gerência total de fornecimento, em adequação aos objetivos organizacionais. (LEENDERS \& FEARON, 1997 apud MENEZES, SILVA E LINHARES, 2007). A eficiência da função compras se torna essencial para o sucesso das organizações inseridas em mercados altamente competitivos.

De acordo com os mesmos, Menezes, Silva e Linhares (2007), as compras públicas devem obedecer aos requisitos de eficiência, eficácia e efetividade, uma que os recursos utilizados para tal advêm dos contribuintes.

A Constituição da República Federativa do Brasil, em seu artigo 370 , inciso
XXI, determina que, salvo casos excepcionais previstos na legislação,
obras, serviços, compras e alienações, deverão ser contratados mediante
licitação pública. Nesse sentido, a Lei n. 8.666 , de 21 de junho de 1993 ,
estabelece as normas gerais sobre licitações e contratos administrativos no
âmbito dos Poderes da União, dos Estados, do Distrito Federal e dos
Municípios, definindo, em seu artigo 22 as modalidades de Concorrência,
Tomada de Preços, Convite, Concurso e Leilão. (MENEZES; SILVA;
LINHARES, 2007, p. 13).

Instituído pela Medida Provisória $\mathrm{n}$. o 2.026, de 4 de maio de 2000, regulamentado pelos Decretos n.os 3.555, de 8 de agosto de 2000 e 3.697, de 21 de

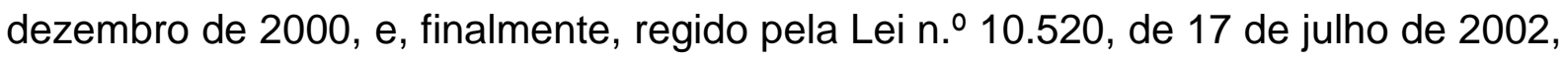


- Pregão representa um aperfeiçoamento no modelo de licitações para a Administração Pública. (MENEZES; SILVA; LINHARES, 2007).

De acordo com SLTI/MP (2000), essa modalidade possibilita o incremento da competitividade e a ampliação das oportunidades de participação nos processos de licitação, contribuindo para a redução das despesas, sobretudo as de custeio da máquina administrativa, indo ao encontro das metas de ajuste fiscal. (MENEZES; SILVA; LINHARES, 2007, p. 13).

No Pregão, a disputa ocorre em sessão pública, através de propostas e lances, com a classificação e a habilitação do licitante que apresente a proposta de menor preço. Quando utiliza recursos de tecnologia da informação, essa espécie recebe o nome de Pregão Eletrônico que, "no âmbito da Administração Pública Federal, compreendidos os três Poderes, se realiza através do Comprasnet, o portal de compras do Governo Federal na Internet”, o que possibilita a participação de maior número de fornecedores que encontram-se em diversas localizações geográficas. (MENEZES; SILVA; LINHARES, 2007).

Neibuhr (2004) salienta ainda que o pregão é uma modalidade de licitação destinada a aquisição de bens e serviços considerados comuns, ou seja, aqueles que podem ser definidos no edital por meio de especificações usuais no mercado. Assim, "sua aplicação só é possível para a aquisição de bens ou serviços com características de padronização", que proporcionem a possibilidade de comparação e julgamento das propostas com base exclusivamente no critério de melhor preço. (MENEZES; SILVA; LINHARES, 2007, p. 14).

A instituição da modalidade de Pregão Eletrônico nos processos de licitação da Administração Pública Brasileira, assim como a própria criação do Portal Comprasnet, devem ser compreendidas como parte da introdução das práticas de Governo Eletrônico, no Brasil. Ruediger (2002) apud Menezes, Silva e Linhares (2007) relata que o termo Governo Eletrônico pode ser visto como o uso de novas tecnologias de informação e comunicação, aplicadas a um amplo arco das funções de governo, especialmente em sua relação com a sociedade.

A redução dos custos e otimização das rotinas e procedimentos nas compras e contratações têm se tornado uma prioridade na Administração Publica Federal. A introdução de novos instrumentos, como tecnologias de informação e revisão de legislação e normas, além da implantação do SIASG, constituíram-se em marcos para a integração sistêmica das unidades responsáveis pelos serviços gerais. 
Neste contexto, o Sistema Integrado de Administração de Serviços Gerais -
SIASG, constitui-se em ferramenta de apoio informatizado aos processos de
compras e contratações. Disseminado por todos os ministérios, autarquias e
fundações, representa uma experiência bem sucedida de informatização
dos procedimentos de compra e contratação governamental no âmbito do
Governo Federal Brasileiro. Como ferramenta de uso unificado e
abrangente, tem contribuílo para a agilização, incremento da competição e
controle dos processos de licitação. Mas recentemente, têm sido
incorporadas ao SIASG novas facilidades das Tecnologias de Informação,
em especial o acesso por meio da Internet, no portal de compras do
Governo Federal - o Comprasnet. (MINISTÉRIO DO PLANEJAMENTO,
ORÇAMENTO E GESTÃO, 2002).

Existe, assim, conforme descrito por Fernandes (2004), uma estrutura de módulos, etapas que compõem o SIASG, descrita a seguir:

a) Cadastro de fornecedores: o Sistema de Cadastramento Unificado de Fornecedores - SICAF, cadastra e habilita parcialmente as pessoas físicas ou jurídicas interessadas em participar das contratações da administração federal.

b) Catálogos de materiais e de serviços: o Catálogo Unificado de Materiais - CATMAT e o Catálogo Unificado de Serviços - CATSER, registram de forma padronizada as especificações técnicas que descrevem e estabelecem requisitos de desempenho para os materiais e serviços adquiridos, integrando os editais e contratos da administração federal.

c) Divulgação eletrônica de editais: o Sistema de Divulgação Eletrônica de Compras - SIDEC, divulga no portal Comprasnet os avisos e editais relativos a contratações e realiza o seu encaminhamento simultâneo para publicação pela Imprensa Nacional.

d) Registro de preços praticados: o Sistema de Preços Praticados SISPP, registra e compara os valores praticados nas contratações da administração federal para subsidiar a determinação dos valores de referência que integram os editais.

e) Emissão de ordem de pagamento: o Sistema de Minuta de Empenho SISME, emite as minutas de empenho para pagamento de bens a serem licitados ou de parcelas de contratos de prestação de serviços que tenham sido executadas, as quais são encaminhadas automaticamente ao sistema de execução financeira da administração federal (SIAFI), que procede ao empenho do respectivo valor. 
f) Gestão de contratos: o Sistema de Gestão de Contratos - SICON, cadastra os extratos de contratos celebrados pela administração federal e procede ao seu encaminhamento para publicação pela Imprensa Nacional, além de registrar os cronogramas físico-financeiros e sua execução para fins de autorização da realização dos pagamentos aos fornecedores.

g) Portal Comprasnet: é o portal de compras do Governo Federal na Internet, localizado no endereço eletrônico www.comprasnet.gov.br, no qual são oferecidos serviços de cadastramento de fornecedores no SICAF, de consulta aos catálogos (CATMAT e CATSER) e aos preços praticados (SISPP), de publicação de avisos, editais, resultados de licitações, extratos de contratos, além dos programas de acesso ao pregão e à cotação eletrônica e da consulta a estatísticas do SIASG e à base de legislação, normas e publicações sobre licitações.

Deste modo, para a gestão dos processos de compras na Administração Pública é necessária a observância das normas que regem todos os procedimentos relativos à Administração de Materiais e de Serviços. 


\section{METODOLOGIA}

\subsection{Tipo de Pesquisa}

Quando aos aspectos metodológicos este trabalho é monográfico, sendo classificado como pesquisa prática, de acordo com Pedro Demo (2000), por ser ligada à práxis, ou seja, à prática em termos de conhecimento científico para fins específicos de intervenção.

Quanto à modalidade de pesquisa com base em seus objetivos, de acordo com Antônio Carlos Gil (1994) e Antônio Raimundo Santos (1999) esta pesquisa é exploratória. Tem como objetivo proporcionar maior familiaridade com o problema, com vistas a torná-lo mais explícito.

A classificação com base nos procedimentos técnicos adotados é uma pesquisa bibliográfica com um estudo de caso.

\subsection{Referências consultadas para 0 delineamento dos Processos das Instituições Federais de Ensino Superior}

1aㅡㄴ Unersidade Estadual de Campinas - UNICAMP:

CAMPOS, Eneida Rached. Metodologia de Gestão por Processos. Campinas : UNICAMP, 2007. Disponível em:

http://www.prdu.unicamp.br/gestão por processos/gestão processos.html. Acesso em: 10/ 03/ 2009.

Universidade Estadual de Campinas. Compras de materiais e serviços. Disponível em: http://www.dga.unicamp.br/Html/Servicos/Compras.htm-. Acesso em:

19/03/2009.

2a Universidade Federal de Santa Catarina- UFSC:

PEREZ,Anderson Luiz Fernandes; POZZEBON, Eliane. Aplicação de sistema multiagente no processo de licitação. Disponível em:

http://www.das.ufsc.br/ eliane/artigos/perez03b.pdf. Acesso em: 12/ 04/ 2009.

\section{3믈 Unersidade Federal de São Carlos- UFSCAR:}

Universidade Federal de São Carlos. Pró-reitora de administração- ProAd. Disponível em: <http://proad.ufscar.br/>. Acesso em: 12/04/2009. 
Universidade Federal do Mato Grosso do Sul. Divisão de compras/GRM. Disponível em: http://www.grm.ufms.br/dico/. Acesso em: 10/04/2009.

5a Universidade de Brasília- UnB:

Universidade de Brasília. Diretoria de recursos materiais. Disponível em: <http://www.drm.unb.br/>. Acesso em: 10/04/2009. 


\section{RESULTADOS}

\subsection{0 caso: Universidade Estadual de Campinas- UNICAMP}

A Universidade Estadual de Campinas (UNICAMP) incorporou a Metodologia de Gestão por Processos na administração e possibilitou a reflexão de maneira estruturada sobre as práticas do dia a dia facilitando a compreensão por todos da Organização.

A falta de visão sistêmica dos processos da organização, aliada a uma preocupação das equipes apenas com suas áreas, menosprezando os clientes internos e externos, são alguns dos fatores que criam um conjunto desalinhado de esforços, que podem fazer pessoas e equipes de boas intenções caminharem em direções diferentes.

Destaca a Universidade Estadual de Campinas (UNICAMP), que a Gestão por Processos traz muitos benefícios para a organização, entre eles:

a) - Concentra o foco no que realmente interessa: o trabalho;

b) - É uma ferramenta para implementação da estratégia organizacional;

c) - Confere simplicidade e agilidade às atividades;

d) - Dota a organização de flexibilidade organizacional;

e) - Facilita a gestão através da identificação de indicadores de desempenho e medição de melhorias nos processos;

f) - Permite uma visão integrada da organização;

g) - Instrumentaliza a aplicação de abordagens inovadoras;

h) - Facilita a gestão do conhecimento organizacional e a gestão de competências.

A metodologia de gestão de processos aqui apresentada é composta de oito etapas que se interrelacionam de forma a propiciar uma visão por processos da organização, foco do estudo. As etapas poderão ser desenvolvidas integralmente e na seqüência apresentada ou, de acordo com a necessidade, poderão ser simplificadas ou não realizadas.

A figura a seguir ilustra a seqüência de etapas da Metodologia de Gestão por Processos: 


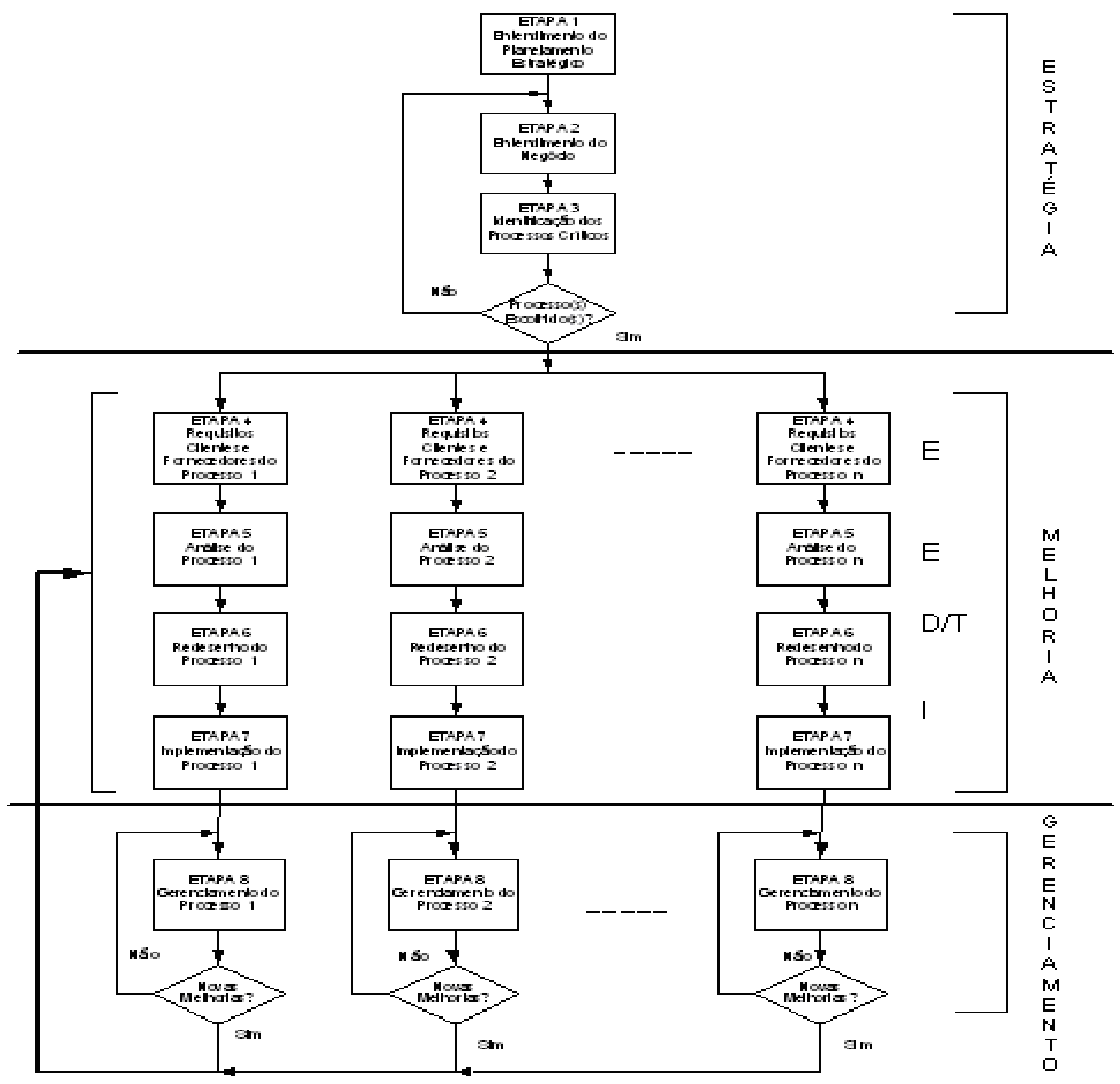

Figura 3 - Fluxo da metodologia da gestão por Processos.

Fonte: http://www.prdu.unicamp.br/gestao por processos/Metodologia 22102007.pdf

A Etapa 1 - Entendimento do Planejamento Estratégico - foi incorporada à metodologia apresentada para reforçar a importância do Planejamento Estratégico como fonte das estratégias da organização e obtenção de resultados coerentes e qualificados na aplicação da Gestão por Processos.

A Etapa 2 - Entendimento do Negócio - objetiva entender o funcionamento da organização e seu comportamento enquanto sistema, identificando seus processos de negócio e suas relações com clientes e fornecedores. É nessa etapa que os envolvidos nos projetos de redesenho de processos, orientados por essa 
metodologia, têm contato com os aspectos conceituais e a forma como o projeto de melhoria será conduzido.

Na Etapa 3 - Identificação dos Processos Críticos - é (são) selecionado(s) o(s) processo(s) crítico(s) que será(ão) alvo(s) do(s) projeto(s) de melhoria. A escolha de um ou vários processos para serem redesenhados ao mesmo tempo, dependerá da força de trabalho disponível para isso. O(s) processo(s) será(ão) selecionado(s) tendo por base as prioridades estabelecidas pela organização vindas do planejamento estratégico ou de oportunidades identificadas que tenham impacto sobre o cliente e sobre a organização.

Da Etapa 4 - Requisitos dos Clientes e Fornecedores do Processo - neste momento, o foco está em um processo específico. Nessa etapa são levantados: os requisitos dos clientes com relação aos produtos/ serviços oferecidos pelo processo; os requisitos dos fornecedores com relação ao processo de forma a proverem insumos adequados às necessidades do mesmo; as necessidades do processo com relação aos clientes e fornecedores, de forma que o trabalho possa ser realizado produzindo as saídas necessárias e dentro dos padrões exigidos.

Para cada um dos requisitos são estabelecidas formas de medí-los e acompanhá-los.

Na Etapa 5 - Análise do Processo Atual -o processo foco da melhoria é analisado passo a passo, identificando-se os pontos de impacto negativo sobre ele, as oportunidades de melhoria e como poderá ser acompanhado de forma a obter-se feedback sobre seu desempenho.

A Etapa 6 - Redesenho do Processo - é a etapa da busca e planejamento das mudanças necessárias para alcançar melhorias na forma como o trabalho passará a ser realizado. São consideradas soluções diversas de forma a identificar aquela que melhor atenda às necessidades e condições do cenário atual.

A Etapa 7 - Implementação do Processo - compreende a implantação efetiva das mudanças (melhorias) planejadas, com a preparação da documentação que dará suporte ao trabalho daí para frente. É nessa etapa que se realiza a divulgação do novo processo e seu treinamento para todos os envolvidos.

A Etapa 8 - Gerenciamento do Processo - corresponde ao acompanhamento, controle e aperfeiçoamento contínuo do novo processo e, portanto, uma etapa 
permanente. É durante esse gerenciamento que novas oportunidades de melhoria do processo são identificadas iniciando-se um novo ciclo de melhoria, a partir da etapa 4. Além de ser a etapa que irá garantir a permanência das melhorias implantadas com um gerenciamento instrumentalizado por indicadores e com um forte papel educativo.

Todas as etapas possuem uma estrutura básica composta dos seguintes itens:

a) Conceitos e valores: onde são abordados aspectos técnicos que dão suporte às atividades desenvolvidas na respectiva etapa. O domínio desses conceitos é gradativo, passando a ser incorporado às ações dos integrantes dos projetos de melhoria e da organização como um todo, à medida que projetos são desenvolvidos continuamente.

b) Objetivos: apresentam em linhas gerais a que se propõe a etapa.

c) Pré-requisitos: condições mínimas desejáveis para que a etapa se inicie de forma a alcançar os objetivos a que se destina.

d) Mapa de atividades e participações: apresenta, de forma gráfica, a seqüência padrão das atividades desenvolvidas na etapa e seus respectivos participantes.

e) Roteiro de trabalho: descreve em maior detalhe como a etapa deve ser desenvolvida, atividade por atividade, orientando como o trabalho deve ser realizado. Nas atividades são feitas referências aos Anexos, que contém técnicas, padrões e sugestões, e que devem ser utilizados na medida que forem referenciados.

f) - Produtos: relaciona os produtos resultantes da etapa, que são a base para a documentação do projeto.

No seu planejamento estratégico de 2003, a Pró Reitoria de Desenvolvimento Universitário (PRDU) estabeleceu como um dos seus objetivos estratégicos a incorporação da Gestão por processos na Administração. Esse objetivo foi fortalecido dentro da PRDU pela preocupação em reorganizar e melhorar seus processos, visando responder às mudanças, maximizar as oportunidades e atender seus clientes/usuários da melhor forma buscando sua satisfação.

No período de 2003 a 2005 com a criação do Grupo de Gestão de Processos (GEPRO), equipe responsável pela condução do objetivo estratégico, obtiveram-se 
resultados importantes dentro da PRDU e do Hospital das Clínicas. Diante desses resultados e das experiências adquiridas, a PRDU ratificou esse objetivo na revisão de seu Plano de 2005 ampliando o escopo para atingir todos os órgãos e unidades da Unicamp.

E foi nesse sentido que o Grupo GEPRO, ampliou o curso de formação de facilitadores com 32 horas para outro de equipes multidisciplinares com 100 horas. Nesse novo programa foram incluídas várias disciplinas, inclusive a que trata de desenvolvimento de pessoas. Inclusão de temas voltados ao desenvolvimento pessoal foi necessária, pois, o engajamento individual das pessoas, a partir do conhecimento e compreensão do que se deseja de cada um é essencial para a obtenção dos resultados globais esperados pela instituição.

A expectativa com a formação dessas equipes multidisciplinares consiste em conduzir a revisão e melhoria de seus processos críticos e conseguir resultados que reduzam as insuficiências e os erros resultantes de uma repetição de atividades e informações.

As aquisições de materiais ou serviços realizadas na Universidade obedecem a toda Legislação estabelecida no estatuto de licitações e contratos. A instrução DGA no 43 contem toda a conceituação e procedimentos pertinentes à formalização dos processos, em especial quanto à utilização do sistema informatizado.

As solicitações para aquisição de materiais ou serviços por dispensa de licitação - até $R \$ 8.000,00$ para compras e serviços comuns e até $R \$ 15.000,00$ para obras e serviços de engenharia - devem ocorrer mediante preenchimento Pedido de Material/Serviço e da Planilha de Custos. As aquisições são efetuadas à luz da Lei Federal 8.666/93 e da Instrução DGA nº 34.

Conforme esta Instrução, a Coordenadora da Administração Geral, no uso de suas atribuições, resolveu estabelecer regras e procedimentos, no âmbito desta Universidade, visando à legalidade do procedimento e à uniformidade na formalização dos processos de compras, obras e serviços, através de dispensa de licitação, nos termos do artigo 24 inciso I e II da Lei Federal 8.666/93. Assim, descrito: 


\section{APRESENTAÇAO DO PROBLEMA UNICAMP}

A seguir como se apresenta o problema referente ao processo de compras da Universidade Estadual de Campinas - UNICAMP.

1. São dispensáveis de licitação as aquisições de materiais/contratação de serviços cujos montantes não superem os limites estabelecidos pelo artigo 24 incisos I e II da Lei Federal ํㅜ 8.666/93. Esses limites são considerados por material ou família de materiais/serviços similares, e por exercício.

2. A Solicitação de Material/Serviço deverá estar assinada pelo responsável do departamento/setor e autorizada pelo responsável da Unidade/Órgão.

3. A Planilha de Custos deverá conter, no mínimo, três fornecedores. Na impossibilidade de se obter a quantidade mínima de fornecedores, por limitação no mercado, o processo deverá contemplar formalmente as devidas justificativas.

3.1. Quando a impossibilidade for decorrente de aquisição através de fornecedor exclusivo, o processo deverá conter:

a) Justificativa técnica sobre a escolha daquela marca e não de um produto similar; e;

b) Cópia da declaração de exclusividade emitida por órgão de classe, sindicato, etc.

4. É vedada às Unidades/Órgãos a aquisição através de dispensa de licitação, ou qualquer outro meio, de itens pertencentes ao estoque do Almoxarifado Central. As exceções serão justificadas em cada processo, e aceitas apenas nas seguintes situações:

a) Quando o material adquirido encontrar-se comprovadamente em falta no Almoxarifado Central na data do recebimento do pedido de compra;

b) Quando o preço encontrado for inferior ao do Almoxarifado Central; ou

c) Quando a marca/modelo disponível no Almoxarifado Central não atender a requisito técnico específico da Unidade/Órgão.

\section{II - PROCEDIMENTOS PARA AS UNIDADES/ÓRGÃOS COMPRADORES}


5. A Unidade/Órgão compradora deverá, inicialmente, requerer a autuação do processo, nos termos das normas gerais de Protocolo.

6. O processo deverá ser instruído pela Unidade/Órgão compradora, com:

a) Solicitação de Material/Serviço devidamente assinada pelo solicitante, e autorizada pelo Diretor da Unidade/Órgão ou Executor do Convênio/Contrato;

b) Reserva de recursos orçamentários ou extra-orçamentários;

c) Propostas das empresas citadas na Planilha de custos, devidamente assinadas, com indicação clara e precisa sobre a isenção do ICMS;

c.1) Tratando-se de aquisição de valor inferior a $R \$ 2.000,00$ juntar somente a proposta da empresa vencedora, devidamente assinada.

d) Planilha de custos, devidamente assinadas/ identificadas pelo comprador, contendo os seguintes elementos:

d.1) Descrição clara do objeto;

d.1.1) Em se tratando de aquisição de equipamentos de informática deve-se obter junto ao Centro de Manutenção de Equipamentos - CEMEQ, análise da descrição do bem a ser adquirido, juntamente com as cláusulas especiais que devem ser atendidas pelo Fornecedor;

d.1.2) Em se tratando de aquisição de equipamentos hospitalares deve-se obter junto ao Centro de Engenharia Biomédica - CEB, análise da descrição do bem a ser adquirido, juntamente com as cláusulas especiais que devem ser atendidas pelo Fornecedor;

d.2) Quantidade, unidade de medida, valor unitário e total por item e por fornecedor;

d.3) Prazo de entrega;

d.4) Validade da proposta;

d.5) Condições de pagamento;

d.6) Prazo de garantia, se for o caso;

d.7) Nome e telefone, fax e e-mail de contato da empresa; e,

d.8) Identificação, data e assinatura do servidor designado para elaboração da planilha;

e) Comparativo de preço pago na última compra e registro de negociação quando for o caso; 
f) Ato de dispensa de licitação conforme Lei Federal 8.666/93, com indicação do ato delegatório de competência à autoridade subscritora;

g) Autorização de Fornecimento - AF devidamente bloqueada ou Compromisso de Outras Despesas, Nota de Empenho - NE ou Nota Extra Orçamentária - NEO e Autorização de Fornecimento definitiva;

g.1) A AF bloqueada e a NEO devem ser assinadas pelo Ordenador da Despesa;

g.2) A AF definitiva deve ser assinada pelo Ordenador da Despesa ou pelo Chefe do Órgão de Compra, fazendo constar logo abaixo da assinatura, o próprio nome e o cargo que ocupa, conforme artigo 60 da instrução DGA ㄲo 43/2002.

h) Comprovante de envio da AF ao fornecedor;

i) Nota Fiscal/Fatura;

j) Recebimento, atestado preferencialmente pelo solicitante ou almoxarife, não devendo ser atestado o recebimento pelos compradores (segregação de funções);e,

k) Autorização para Liquidação devidamente preenchida e assinada pelo servidor designado nos termos do item 70 da Instrução DGA ํo 36/2002.

k.1) Eventuais saldos de verba a serem anulados deverão ser informados através de despacho do Órgão de Compras para fins de inclusão na Autorização para Liquidação conforme Cap. XVII da Instrução DGA oํ 43/2002.

7. Após o recebimento do material/serviço, a cópia da nota fiscal/fatura deverá ser enviada ao Almoxarifado Central e seccional, conforme o caso, para registro no sistema de recebimento físico.

8. Devidamente formalizado, o processo será enviado ao Órgão Liquidante, para liquidação da despesa, no prazo mínimo de 03 dias úteis, antes do vencimento do pagamento, cuja liquidação deverá ocorrer com pelo menos 01 dia útil de antecedência.

9. O pagamento será efetuado pela Área de Finanças da DGA, o qual deverá ocorrer no vencimento em cumprimento à cronologia de pagamento. 
a) Eventuais processos enviados para liquidação com atraso, deverão ser devidamente justificados e enviados a Área de Finanças, tendo em vista o artigo 74 da Instrução no 01/2002 do Tribunal de Contas do Estado de São Paulo - TCESP.

10. Após a formalização do pagamento o Órgão Liquidante deverá:

a) Enviar o processo ao Controle Patrimonial quando se tratar de material permanente; e,

b) Enviar o processo ao Arquivo da Unidade para encerramento e arquivamento quando se tratar de material de consumo.

\section{III - PROCEDIMENTOS PARA ÓRGÃOS DA UNIDADE 01 - REITORIA}

11. Os Órgãos da Unidade Reitoria deverão preencher o formulário Solicitação de Material/Serviço, informando a descrição clara do objeto, a fonte de recurso, e enviálo devidamente assinado pelo solicitante e autorizado pelo Diretor do Órgão ou Executor do Convênio/Contrato, à Seção de Pequenas Aquisições/Compras da Área de Suprimentos da DGA.

12. Ao receber a solicitação, a Seção de Pequenas Aquisições deverá:

a) Providenciar a estimativa na Planilha de Custo e a aprovação do solicitante, conforme opção assinalada no formulário de solicitação;

b) Enviar a Solicitação de Material/Serviço e a Planilha de Custo à Área de Serviços Complementares/Controle de Documentação - ASC/CDOC para abertura e autuação do processo, solicitando o encaminhamento direto ao Apoio Orçamentário da Coordenadoria da DGA para reserva de recursos.

13. Ao receber o processo com a reserva do recurso, a Seção de Pequenas Aquisições deverá instruir o processo com:

a) As propostas das empresas, devidamente assinadas, com indicação clara e precisa sobre a isenção do ICMS;

a.1) Tratando-se de aquisição de valor inferior a $R \$ 2.000,00$ juntar somente a proposta da empresa vencedora, devidamente assinada.

b) A planilha de custos, contendo os seguintes elementos:

b.1) Descrição clara do objeto; 
b.1.1) Em se tratando de aquisição de equipamentos de informática deve-se obter junto ao Centro de Manutenção de Equipamentos - CEMEQ, análise da descrição do bem a ser adquirido, juntamente com as cláusulas especiais que devem ser atendidas pelo Fornecedor.

b.1.2) Em se tratando de aquisição de equipamentos hospitalares deve-se obter junto ao Centro de Engenharia Biomédica - CEB, análise da descrição do bem a ser adquirido, juntamente com as cláusulas especiais que devem ser atendidas pelo Fornecedor.

b.2) Quantidade, unidade de medida, valor unitário e total por item e por fornecedor;

b.3) Prazo de entrega;

b.4) Validade da proposta;

b.5) Condições de pagamento;

b.6) Prazo de garantia, se for o caso;

b.7) Nome e telefone, fax e e-mail de contato da empresa, e;

b.8) Identificação, data e assinatura do servidor designado para elaboração da planilha.

c) O comparativo de preço pago na última compra e registro de negociação quando for o caso;

b) $O$ ato de dispensa de licitação conforme Lei Federal 8.666/93, com indicação do ato delegatório de competência à autoridade subscritora, e;

d) a Autorização de Fornecimento, devidamente bloqueada, ou Compromisso de Outras Despesas, Nota de Empenho - NE ou Nota Extra Orçamentária - NEO e Autorização de Fornecimento definitiva;

d.1) A AF bloqueada e a NEO devem ser assinadas pelo Ordenador da Despesa;

d.2) A AF definitiva deve ser assinada pelo Ordenador da Despesa ou pelo Chefe do Órgão de Compra, fazendo constar logo abaixo da assinatura, o próprio nome e o cargo que ocupa, conforme artigo 60 da Instrução DGA no 43/2002.

e) Comprovante de envio da AF ao fornecedor;

14. O Almoxarifado Central deverá efetuar o recebimento do material, de acordo com os itens 63 e 64 da Instrução DGA no 36/2002 atestando o recebimento no 
documento fiscal, com a devida identificação (assinatura, nome por extenso e matrícula do servidor) e após conferência, deverá enviar a nota fiscal/fatura à Seção de Pequenas Aquisições da Área de Suprimentos da DGA. Instrução DGA no 34/02, 29 de agosto de 2002

15. Ao receber a Nota Fiscal/Fatura a Seção de Pequenas Aquisições deverá:

a) Juntar no processo a nota fiscal/fatura;

b) Elaborar a Autorização para Liquidação da despesa nos termos do item 65 a 73 da Instrução DGA no 36/2002;

b.1) Eventuais saldos de verba a serem anulados deverão ser informados através de despacho do Órgão de Compras para fins de inclusão na Autorização para Liquidação conforme Cap. XVII da Instrução DGA no 43/2002.

16. Devidamente formalizado, o processo será enviado ao Órgão Liquidante, para liquidação da despesa, no prazo mínimo de 03 dias úteis, antes do vencimento do pagamento, cuja liquidação deverá ocorrer com pelo menos 01 dia útil de antecedência.

17. O pagamento será efetuado pela Área de Finanças da DGA, o qual deverá ocorrer no vencimento em cumprimento à cronologia de pagamento.

a) Eventuais processos enviados para liquidação com atraso, deverão ser devidamente justificados e enviados a Área de Finanças, tendo em vista o artigo 74 da Instrução no 01/2002 do Tribunal de Contas do Estado de São Paulo - TCESP.

18. Após o pagamento a ARCC deverá:

a) Enviar o processo ao Controle Patrimonial quando se tratar de material permanente, e;

b) Enviar o processo à ASC/CDOC para encerramento e arquivamento quando se tratar de material de consumo. 


\section{IV- PROCEDIMENTOS ESPECIAIS}

19. Havendo necessidade de alteração do número da documentação hábil à comprovação da necessidade de alteração da conta e/ou agência bancária, será aquela emitida e devidamente assinada pelo fornecedor.

20. A falta de comprovação das razões que motivaram a alteração da conta e/ou agência, constante da Autorização de Fornecimento, ensejará o Órgão Liquidante a não proceder a liquidação da despesa e, conseqüentemente, não efetuar o pagamento e devolver os autos à origem, para sanar a irregularidade procedimental.

\section{V - DAS RESPONSABILIDADES}

21. É de inteira responsabilidade do subscritor da planilha de custos, a veracidade das informações colhidas, respondendo por quaisquer irregularidades que venham a ser apuradas.

22. É de responsabilidade da Unidade/Órgão, toda e qualquer irregularidade apurada nos autos do processo, respondendo solidariamente, aquele que, direta ou indiretamente, contribuiu para o fato, observando, entre outras legislações pertinentes o capítulo IV da Lei Federal 8.666/93. Instrução DGA no 34/02, 29 de agosto de 2002.

\section{VI - DOS ANEXOS}

23. Integram a presente Instrução:

- Solicitação de Material;

- Serviço Planilha de Custo.

24. É de responsabilidade da Área de Suprimentos da DGA manter esta Instrução atualizada.

\subsection{2o caso: relato do caso da Universidade Federal de Santa Catarina - UFSC}

A Universidade Federal de Santa Catarina (UFSC), apresentou um sistema multiagente aplicado ao processo de licitação pública. Os sistemas multiagentes visam solucionar problemas de forma distribuída, onde cada agente possui uma certa autonomia e é responsável por uma determinada tarefa. A aplicação de 
sistemas multiagentes no processo de licitação pública visa auxiliar os especialistas na tomada de decisão com o objetivo de selecionar a proposta mais vantajosa para a Administração Pública.

A licitação é um procedimento administrativo destinado a selecionar, entre outras a proposta mais vantajosa para a Administração Pública. Todos os órgãos da mesma, das esferas federal, estadual, e municipal e demais entidades controladas direta ou indiretamente pela União, Estados, Distrito Federal e Municípios, quando contratam com terceiros, obras, serviços, compras, alienações, permissões e locações, devem, obrigatoriamente, se submeter ao procedimento administrativo prévio de licitação, conforme a legislação em vigor.

Infelizmente, pela precária estrutura material e pessoal de que dispõem, o Poder Público é quase sempre lesado nas compras dos bens e serviços que necessita para o exercício de suas atividades administrativas (FIGUEIREDO. J.R, 2002).

Para que o processo de licitação atenda seus requisitos tanto jurídicos quanto materiais, faz-se necessário a utilização de um sistema capaz de auxiliar a comissão permanente de licitação à tomada de decisões com o objetivo de julgar e escolher a melhor proposta a fim de atender o objetivo da licitação.

A utilização de um sistema multiagente é justificável, pois, um processo de licitação pública é naturalmente distribuído sendo composto de três entidades básicas: a empresa ou órgão público que elabora o edital de licitação, os fornecedores que elaboram as propostas e os especialistas que analisam todas as propostas recebidas e apontam um ganhador. O sistema desenvolvido, intitulado de SMLP, Sistema Multiagente para Licitação Pública, contempla somente a licitação do tipo carta convite, na qual a empresa ou órgão público elabora o edital de licitação e o encaminha para alguns fornecedores previamente cadastrados. $O$ SMLP pode ser adaptado para contemplar outros tipos de licitações sendo necessário fazer poucas modificações. 


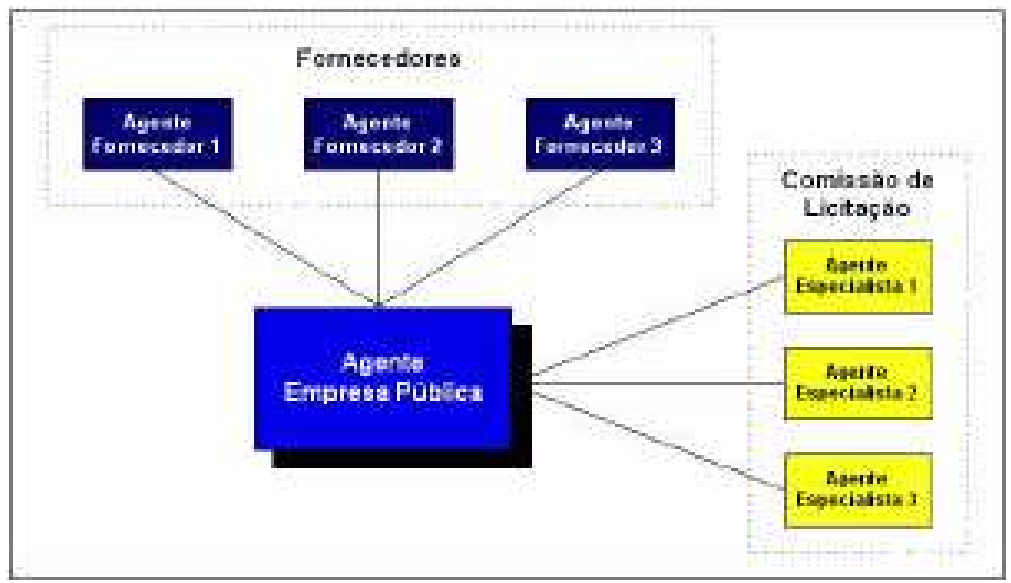

Figura 4 - Representação hierárquica dos agentes participantes do processo licitatório.

Fonte: UNIVERSIDADE FEDERAL DE SANTA CATARINA - UFSC

http://www.das.ufsc.br/ eliane/artigos/perez03b.pdf

\section{3. $3^{\circ}$ caso: Universidade Federal de São Carlos- UFSCAR}

A Universidade Federal de São Carlos (UFSCAR) por meio de sua página na internet demonstra passo a passo de que forma é conduzido o pedido de compras de matérias de consumo, serviço, materiais permanentes e equipamentos, como descrito a seguir.

A solicitação para aquisição de material de consumo primeiramente necessita da instalação do Programa de Requisições, em que se deve preencher todos os campos do formulário REQUISIÇÃO DE COMPRAS OU SERVIÇOS / ORDEM DE DESPESA, o qual traz a descrição completa e correta dos produtos e valor estimado, além dos carimbos e respectivas assinaturas. Deve-se então, encaminhar uma requisição para cada grupo de materiais de mesma natureza ou linha de fornecimento.

A especificação dos produtos a serem adquiridos deve ser bem detalhada, sem constar código ou sinais que possam sugerir determinada marca. E sempre que possível, deve se indicar prováveis fornecedores.

Em se tratando de materiais de produção exclusiva de um fornecedor, é importante constar esta informação no pedido. Se possível, anexar orçamento e o certificado de exclusividade expedido por entidade de classe industrial/comercial.

A REQUISIÇÃO DE COMPRAS OU SERVIÇOS / ORDEM DE DESPESA, devidamente assinada pelo Ordenador da Despesa, é, desta forma, encaminhada para o Departamento de Controle Orçamentário para verificação quanto à 
classificação correta da alínea (339030) e débito da despesa correspondente, seguindo para o Departamento de Compras para o processamento da aquisição.

Para a aquisição de material permanente e de equipamentos, após a instalação do Programa de Requisições, disponível, deve também se preenchidos todos os campos do formulário REQUISIÇÃO DE COMPRAS OU SERVIÇOS / ORDEM DE DESPESA, trazendo a descrição completa e correta dos bens e valor estimado, além dos carimbos e respectivas assinaturas. Seguindo-se as mesmas etapas de aquisição e requisição de materiais para consumo.

A requisição, então, é feita em (duas) vias: a primeira segue para o processamento da aquisição e a segunda para o Departamento de Almoxarifado. Não é necessária a impressão para arquivo, pois, o programa armazena as requisições emitidas. Não pode conter na mesma requisição itens de consumo e bens permanentes.

O Departamento de Compras, com vistas à racionalização e para evitar fracionamento de despesas de modo a não conflitar com a legislação, pode agrupar pedidos de aquisições similares solicitados por mais de uma unidade, tanto para compra de material de consumo quanto para equipamento e material permanente.

A ausência de carimbo e/ou assinatura bem como o preenchimento incorreto ou incompleto da requisição são motivos para a devolução do documento.

Ao solicitar, a unidade deve verificar antes as formas, as embalagens e as quantidades nas quais o produto está colocado no mercado.

90\% do sucesso de um processo de compras está na origem da requisição, ou seja, na clareza e qualidade do pedido.

\subsection{4 caso: Universidade Federal de Mato Grosso do Sul- UFMS}

A Divisão de Compras da Universidade Federal de Mato Grosso do Sul é uma unidade subordinada administrativamente à Gerência de Recursos Materiais. Portanto, consiste no órgão responsável pela coordenação, execução e controle das atividades relativas à aquisição de materiais e o diligenciamento de fornecedores. Possuindo como objetivos: 
a) Interagir com os usuários e/ou demais órgãos envolvidos, para obtenção de informações concernentes a produtos ou equipamentos a serem adquiridos.

b) Orientar e fiscalizar o processamento da aquisição de material, observadas as normas e legislação específicas.

c) Promover pesquisas de mercado visando o estudo de preços e a qualidade dos produtos disponíveis no mercado.

d) Elaborar um plano de compras, a partir de propostas e prioridades dos órgãos acadêmicos e administrativos e, de acordo com o cronograma de desembolso da Universidade.

e) Prestar subsídios à Gerência, em assuntos relativos a área de compras.

f) Elaborar e expedir normas inerentes ao processamento da aquisição de material e da prestação de serviços, bem como fiscalizar seu cumprimento.

g) Receber, classificar e processar os pedidos de compra de material e de contratação de obras e serviços.

h) Colaborar na elaboração do plano anual e do orçamento da Gerência.

i) Solicitar o material de consumo e permanente necessários à operacionalização da Divisão.

j) Executar a administração patrimonial, de material e de recursos humanos da Divisão.

k) Elaborar relatórios gerenciais.

l) Desenvolver outras atividades dentro de sua área de atuação.

Já o Setor de Cadastro e licitação é o órgão responsável pela elaboração dos processos licitatórios, bem como pela execução e controle das atividades de cadastramento de fornecedores através do Sistema SIASG/SICAF (Sistema de Cadastramento Unificado de Fornecedores), e ainda pelo controle de notas de empenho/fornecedores nos processos de compras. Suas atribuições são:

a) Analisar as solicitações de compras em relação à especificação, grupo de material, quantidade e unidade a ser adquirida;

b) Preparar o processo licitatório em conformidade com a modalidade de licitação estabelecida por lei e torná-la pública aos interessados, através de sistema SIASG/SIDEC (Sistema de Divulgação Eletrônica de Compras e Contratações); 
c) Disponibilizar os editais de licitações aos fornecedores interessados;

d) Dispor o processo licitatório à Comissão Permanente de Licitação CPEL/PRAD, para abertura e julgamento das propostas;

e) Como Unidade Cadastradora junto ao SIASG, disponibilizar ao público, o material necessário para o cadastramento junto ao SICAF (manual, formulários, informações);

f) Proceder à análise da documentação dos interessados no cadastramento, sempre com base na Instrução Normativa MARE 05/95 e Art. 34 da Lei 8.666/93;

g) Após o cadastramento, atualizar os dados de fornecedores, sempre que esse serviço for solicitado pelos interessados;

h) Prestar informações sobre o cadastramento dos fornecedores, toda vez que esse serviço for solicitado;

i) Manter em arquivo próprio, toda a documentação dos fornecedores cadastrados na unidade;

j) Interagir, com os usuários e/ou demais órgãos envolvidos no Sistema, para obtenção de informações concernentes a fornecedores, materiais ou serviços.

k) Receber os processos empenhados, conferir e providenciar a distribuição de notas de empenho aos interessados (fornecedores e almoxarifados) e manter em arquivo de controle até sua finalização.

l) Providenciar registro das notas de empenho para controle de prazos de entrega, controle de saldo e de pagamento através da respectiva ordem bancária.

m) Cobrar, juntos aos fornecedores, a entrega do material empenhado.

n) Após recebimento das notas fiscais oriundas dos almoxarifados, providenciar o respectivo processo de pagamento, encaminhando-o à unidade competente. (Divisão Financeira/CCF/PROPLAN). 


\subsection{O Modelo do Processo de Compras para Universidade de Brasília}

O processo de compra pode ser definido como a aquisição de produtos, bens ou serviços mediante pagamento com valor equivalente aos produtos adquiridos. No caso das instituições públicas, esse processo é realizado por meio de licitação, conforme a Lei 8.666, de 21 de julho de 1993.

O Pedido de Compras, na Universidade de Brasília, é gerado a partir da emissão do documento de solicitação de compras autorizado pelo titular do Centro de Custo ou Departamento, pelo Coordenador do Curso de Pós-Graduação ou pelo executor do convênio e encaminhado à Diretoria de Recursos Materiais (DRM).

Este processo requer algumas etapas, como:

a) Recebimento do pedido de compras com a devida justificativa e documentações exigidas;

b) Processamento da compra dentro das normas legais;

c) Empenhar a compra;

d) Encaminhar o empenho para a empresa vencedora;

e) Contagem do prazo para entrega do bem ou serviço;

f) Recebimento de material no almoxarifado, o serviço, pelo solicitante com o devido atesto no verso da Nota Fiscal (NF);

g) Cobrança de multa no caso de atraso na entrega;

h) Baixar nota no Serviço de Compras Nacionais (SCN);

i) Encaminhar nota fiscal para o Serviço de Almoxarifado (SAL) no caso de material ou equipamento para a devida entrada no estoque;

j) Permanente a nota é encaminhada do SAL para o Serviço de Patrimônio (PAT) para tombamento e incorporação do bem ao patrimônio da Fundação Universidade de Brasília (FUB);

k) Após esse trâmite, encaminhamento da NF para a Diretoria de Contabilidade e Finanças (DCF) para pagamento;

I) No caso de serviço, a Nota é baixada no $\mathrm{SCN}$ e encaminhada diretamente para a DCF onde também é processado o pagamento;

m) Dando por encerrado o processo de compra.

O pedido de compra é, portanto, o instrumento através do qual, o Centro de Custo solicita à Diretoria de Recursos Materiais (DRM), a aquisição de material de 
consumo, permanente/equipamentos e serviços, não disponíveis no estoque do Almoxarifado Central (SAL).

Antes da emissão do pedido o site www.compras.unb.br deve ser consultado para verificar a existência de bens e serviços licitados por meio do Sistema de Registro de Preços - SRP, implementado pela DRM.

A aquisição externa de materiais de consumo que são mantidos no estoque do Almoxarifado Central não é permitida, exceto quando se trata de recursos oriundos de órgãos de fomento à pesquisa científica e tecnológica (CAPES, CNPq, FINEP e outros) ou de convênios que não permitam a requisição junto àquele Almoxarifado.

O Centro de custo deve emitir o pedido de compra por meio do Sistema (SIMAR na tela pedido de compra) e encaminhar à Diretoria de Recursos Materiais, através de um documento (memorando ou ofício) devidamente numerado e assinado pelo Titular do Centro de Custo, pelo Coordenador do Curso de PósGraduação ou pelo executor do Convênio, relacionando o bem ou serviço que deverá ser adquirido e a respectiva justificativa para a compra (obrigatória).

O pedido é, então, recebido na Diretoria de Recursos Materiais (DRM) através de sua Secretaria Administrativa que faz o registro de entrada no sistema UNBDOC, que é o meio pelo qual o solicitante e a equipe de compras têm como monitorar todas as fases do processo e o encaminhar para a DRM;

A DRM confirma a disponibilidade orçamentária; se não há, devolve o pedido ao solicitante.

Após, verifica se o pedido está discriminado corretamente, se não estiver, o devolve ao solicitante para providenciar a correção, e, em se tratando de equipamentos de informática e aparelho de ar condicionado não contemplados pela padronização da FUB, serão encaminhados ao Centro de Manutenção de Equipamentos (CME), para a devida especificação.

A mesma relaciona pedidos para fins de aquisição em lotes, especificamente quando se trata de equipamentos de informática, móveis, equipamentos de laboratórios e equipamentos de áudio/vídeo/som/imagens, devido ao grande volume de compras. Os demais grupos de materiais são adquiridos de acordo com a demanda. 
A DRM providencia também, a avaliação de preços estimados junto ao mercado para definir a modalidade da licitação em conformidade com a lei e em atendimento à recomendação do Tribunal de Contas da União (TCU).

Quando a modalidade de licitação a ser executada é do tipo convite conforme art. 23, inciso II, alínea a, da lei 8.666/93, ou de dispensa conforme art. 24, inciso II, da lei 8.666/93, ou ainda quando a aquisição de bens destinados exclusivamente à pesquisa científica e tecnológica com recursos concedidos pela CAPES, FINEP, CNPq ou outras instituições de fomento a pesquisa credenciadas pelo CNPq para esse fim específico conforme art. 24, inciso XXI da lei 8.666/93, e inexigibilidade conforme art. 25 inciso I, encaminham-se estes pedidos para o SCN.

A DRM processa a licitação, providencia a emissão, aprovação e entrega do empenho ao fornecedor, quando a modalidade de licitação é de Pregão eletrônico.

Conforme lei 10.520/2002, permitiu-se a utilização do Pregão para a elaboração de Sistema de Registro de Preços, que guarda previsão no art. 15 da lei 8.666/93, estando regulamentado pelo Decreto 3.931/2001, com redação alterada pelo Decreto 4.342/2002, podendo ser, portanto, presencial ou eletrônico, convencionando-se denominá-lo de Pregão para Sistema de Registro de Preço. (FONSÊCA, 2008). Não sendo essa modalidade, se encaminha o pedido para o Serviço de Compras Nacionais (SCN).

O SCN, assim, providencia a licitação conforme despacho da DRM, de acordo com as fases descritas abaixo:

a) Se convite, escolhe e convida no mínimo três interessados, do ramo pertinente do objeto, cadastrados ou não (parágrafo 3o do art. 22). Afixa em local apropriado (como quadro de avisos) a cópia do instrumento convocatório. O convite estende-se aos demais cadastrados do ramo que manifestarem interesse até 24 horas antes da apresentação das propostas. Essa possibilidade de participação de um interessado, não formalmente convidado, é sem dúvida um reforço à Universidade da participação. $\mathrm{O}$ prazo de publicação para essa modalidade é de 05 (cinco) dias úteis conforme art. 21 inciso IV da lei 8.666/93.

b) Dispensa, se junto ao pedido, houver anexadas as propostas informadas pelo solicitante, então, consulta-se a situação do fornecedor junto ao Sistema de Cadastramento Unificado de Fornecedores (SICAF) ou 
documentações exigidas, para proceder a compra pelo menor valor ou maior com a devida justificativa do solicitante no caso de dispensa de licitação;

c) Se junto ao pedido não houver as propostas, o SCN providencia junto ao mercado, fazendo as mesmas consultas do item anterior;

d) Solicita junto ao departamento de origem do pedido, parecer quanto ao melhor preço ou a melhor proposta;

e) Publica-se a dispensa já informando a empresa vencedora;

f) No caso de inexigibilidade, publica-se com a devida justificativa de exclusividade;

g) Verifica a validade das propostas (que devem ser no mínimo 3);

h) Encaminha para emissão de Nota de Empenho;

i) Posteriormente, há conferência, assinatura e entrega da Nota de Empenho ao fornecedor;

j) E então, envia-se a pasta do processo à Seção de Cadastro e Controle de fornecedores (SCF).

A SCF faz a entrada da Nota de Empenho junto ao Sistema de Materiais (SIMAR); realiza a contagem do prazo para a entrega do material/equipamento ou serviço; emite carta de cobrança caso a entrega não seja feita dentro do prazo; cobra multa por atraso na entrega; informa suspensão da empresa junto ao SICAF, caso ela se negue a entregar o produto ou serviço objeto da licitação; recebe Nota fiscal encaminhada pelo SAL devidamente atestada; baixa a Nota Fiscal e a devolve ao Almoxarifado para processar entrada no estoque; recebe Nota fiscal de serviço devidamente atestada, que é baixada e encaminhada para a Diretoria de Contabilidade e Finanças (DCF) para pagamento; encerra o processo após o encaminhamento da Nota fiscal para pagamento; e encaminha o processo para numeração de páginas onde em seguida é arquivado.

Entre as atribuições do Serviço de Almoxarifado, destacam-se:

a) Recebimento da mercadoria objeto da licitação;

b) Conferência da mesma;

c) Entrada da mercadoria no estoque;

d) Atesto de recebimento da mercadoria no verso da Nota Fiscal; 
e) Encaminhamento da nota para seção de cadastro junto ao SCN que faz a devida baixa e devolve ao SAL;

f) Encaminhamento da nota para Serviço de Patrimônio (PAT), se material permanente, para incorporação do bem ao patrimônio da Fundação Universidade de Brasília (FUB) e seu devido tombamento;

g) Após tombamento o Serviço de Patrimônio encaminha a Nota Fiscal ao DCF para pagamento;

h) Entrega da mercadoria objeto da compra ao solicitante;

i) Encerramento do processo da compra;

j) Encaminhamento para o arquivo do SCN.

Segue abaixo figura dos fluxogramas: visão Geral do processo de compras da Universidade de Brasília: pregão, convite, dispensa e inexigibilidade, sobre aquisições de materiais de consumo, equipamentos e materiais permanentes.

As aquisições de serviços seguem os mesmos passos dos quadros mencionados acima, encerrando-se o processo com o recebimento e atesto da execução do serviço junto ao solicitante, sendo baixada a nota fiscal no Setor de Cadastro e encaminhada para o Serviço de Contabilidade para liquidação, não sendo necessária a passagem dela pelo Serviço de Almoxarifado e o Serviço de Patrimônio.

A Figura 5 mostra a visão geral do processo de compras onde está caracterizado as modalidades de licitação executada por essa Diretoria de Recursos Materiais (DRM) e o Serviço de Compras Nacionais (SCN), desde o recebimento do pedido na secretaria da DRM até sua liquidação no Setor de Contabilidade.

A figura 6A mostra as fazes do Pregão e por onde elas passam, desde a elaboração da minuta do Edital até a entrega do bem ou serviço ao solicitante e com a liquidação do empenho junto ao Setor de Contabilidade

A figura 6B mostra os atores que fazem parte da execução da modalidade de licitação, Pregão, que são: Diretoria de Recursos Materiais (DRM), Procuradoria Jurídica (PJU), o pregoeiro, o setor de execução do Serviço de Compras Nacionais (SCN), setor de Cadastro de Fornecedores (SCF), Serviço de Almoxarifado (SAL), Serviço de Patrimônio (PAT) e Diretoria de Contabilidade e Finanças (DCF). 
A figura 7A mostra as fazes do Convite e por onde elas passam, desde a elaboração da minuta do Edital até a entrega do bem ou serviço ao solicitante e com a liquidação do empenho junto ao Setor de Contabilidade

A figura 7B mostra os atores que fazem parte da execução da modalidade de licitação, Convite, que são: Serviço de Compras Nacionais (SCN), Procuradoria Jurídica (PJU), o Chefe do Serviço de Compras Nacionais, que é o presidente da Comissão Permanente de Licitação (CPL), o setor de execução do Serviço de Compras Nacionais (SCN), setor de Cadastro de Fornecedores (SCF), Serviço de Almoxarifado (SAL), Serviço de Patrimônio (PAT) e Diretoria de Contabilidade e Finanças (DCF).

A figura 8A mostra as fazes da Dispensa de Licitação desde a solicitação das propostas até a entrega do bem ou serviço ao solicitante e com a liquidação do empenho junto ao Setor de Contabilidade

A figura 8B mostra os atores que fazem parte da execução da modalidade de dispensa de licitação que são: Serviço de Compras Nacionais (SCN), setor de execução do Serviço de Compras Nacionais (SCN), setor de Cadastro de Fornecedores (SCF), Serviço de Almoxarifado (SAL), Serviço de Patrimônio (PAT) e Diretoria de Contabilidade e Finanças (DCF).

A figura 9A mostra as fazes da inexigibilidade com a solicitação da proposta, junto a certificação de exclusividade, ratificação e publicação até a entrega do bem ou serviço ao solicitante e com a liquidação do empenho junto ao Setor de Contabilidade

A figura 9B mostra os atores que fazem parte da execução da inexigibilidade que são: Serviço de Compras Nacionais (SCN), setor de execução do Serviço de Compras Nacionais (SCN), setor de Cadastro de Fornecedores (SCF), Serviço de Almoxarifado (SAL), Serviço de Patrimônio (PAT) e Diretoria de Contabilidade e Finanças (DCF).

A figura 10 mostra o Setor de Cadastro, onde é feito o controle e prazo de entrega do bem ou serviço, originário da nota de empenho, cobrança de multa por atraso na entrega, emissão de carta cobrança quando o fornecedor por nenhum motivo justifique o atraso na entrega do bem ou serviço, faz suspensão da empresa junto ao SICAF, caso ela se negue a entregar o bem ou serviço, baixa as notas após 
a entrega do bem ou serviço e encaminha para o Setor de Contabilidade para liquidação quando é serviço e para o Serviço de Almoxarifado quando o bem pode ser material de consumo ou permanente, nesse último caso a nota é encaminhada para o Serviço de Patrimônio e após ser tombado o bem é encaminhada para liquidação no Setor de Contabilidade. Orienta fornecedores para cadastro, emite certidões, atualiza certidões de fornecedores e faz habilitação parcial dos mesmos.

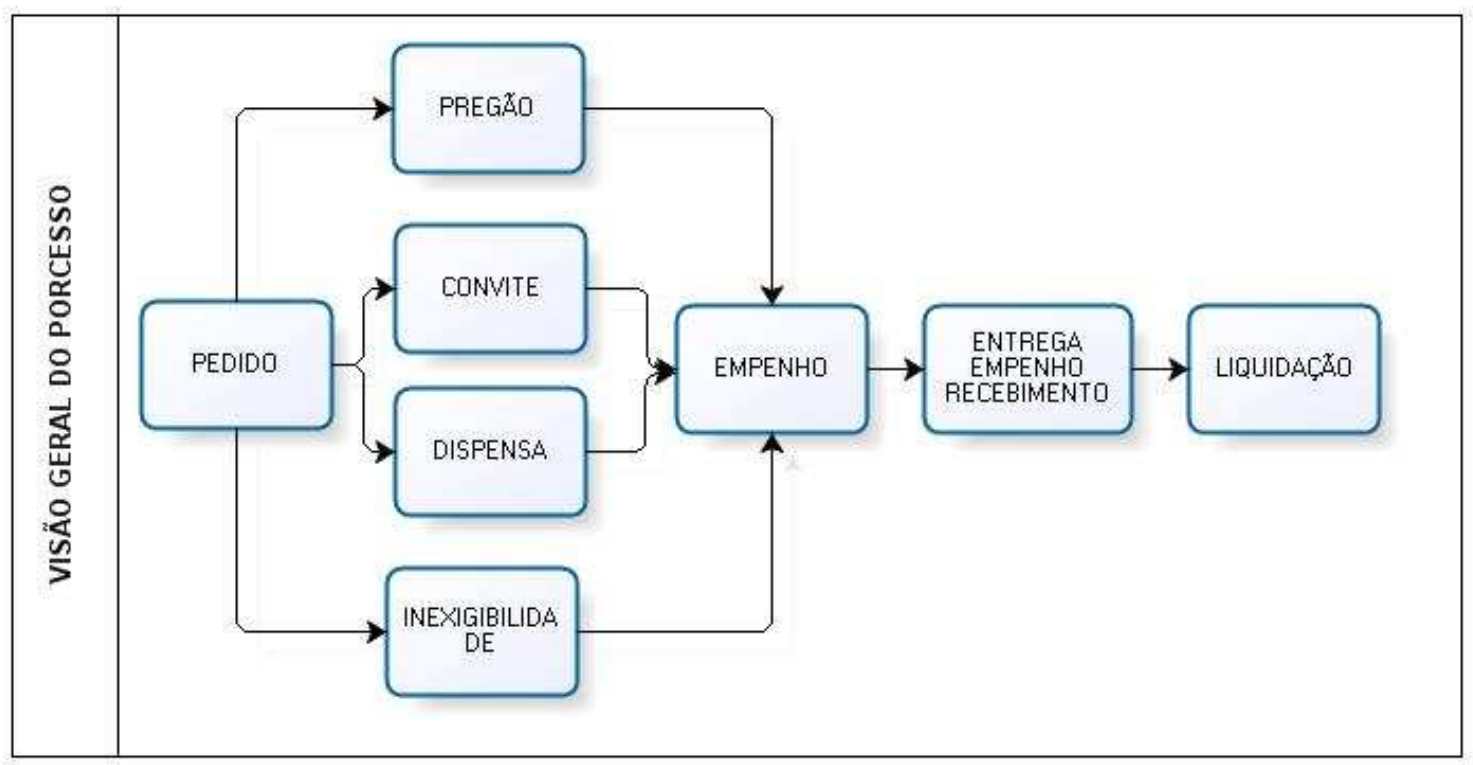

Figura 5 - Visão Geral do Processo Fonte: Elaboração própria

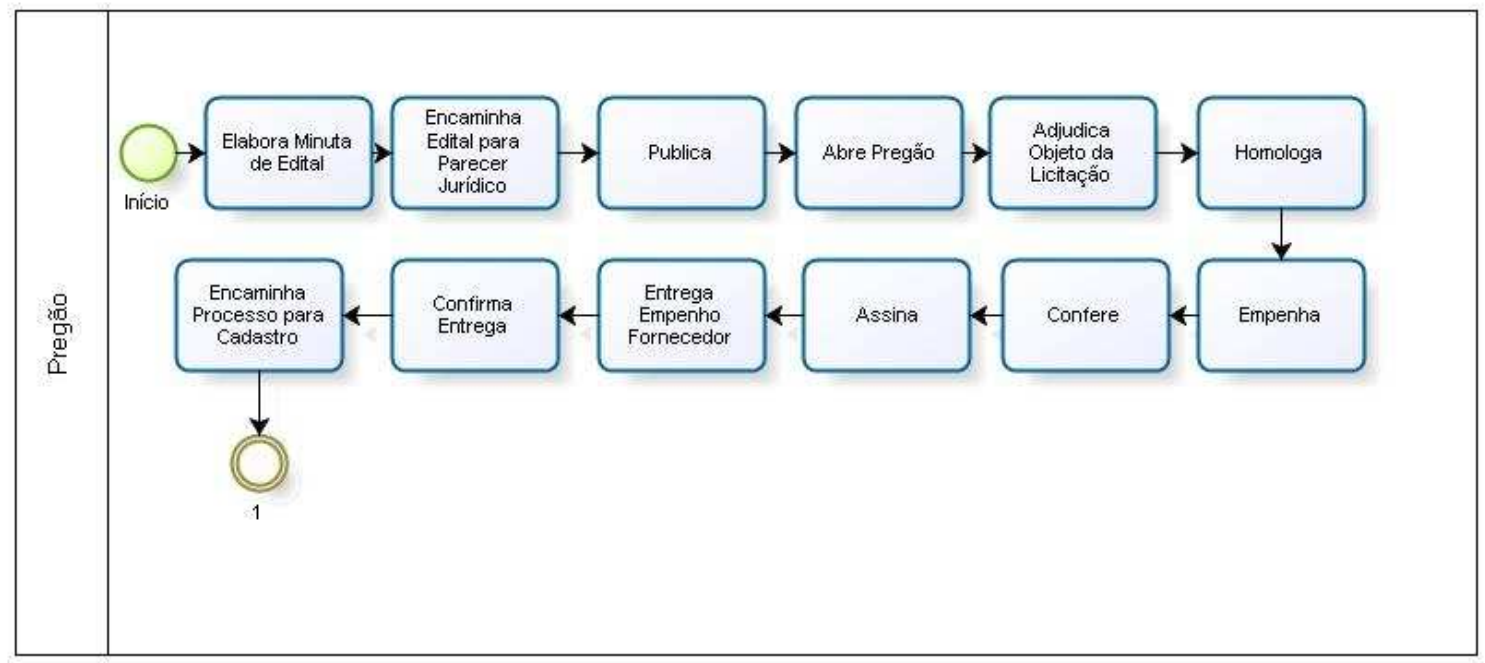

Figura 6A - Pregão

Fonte: Elaboração própria 


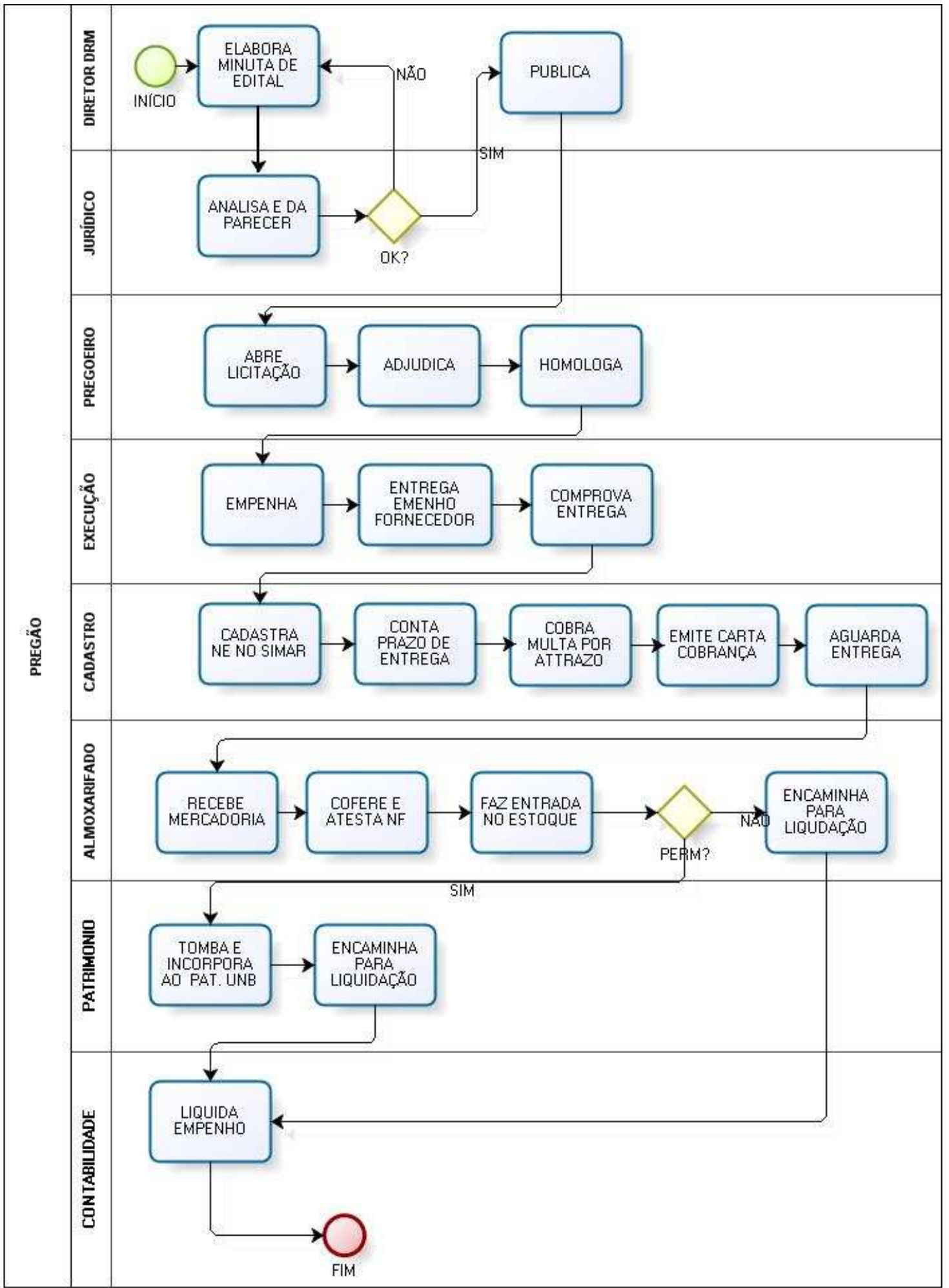

Figura 6B - Pregão

Fonte: Elaboração própria 


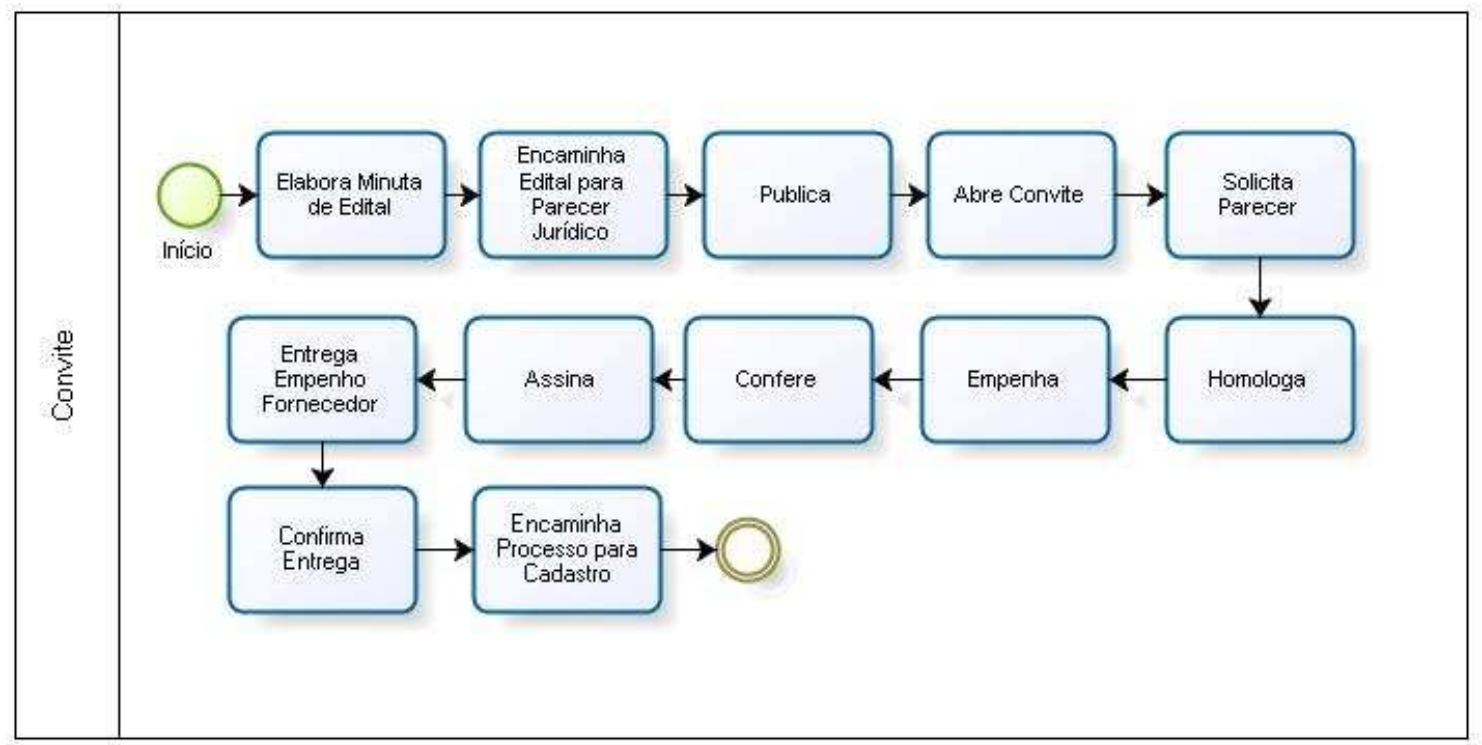

Figura 7A - Convite

Fonte: Elaboração própria 


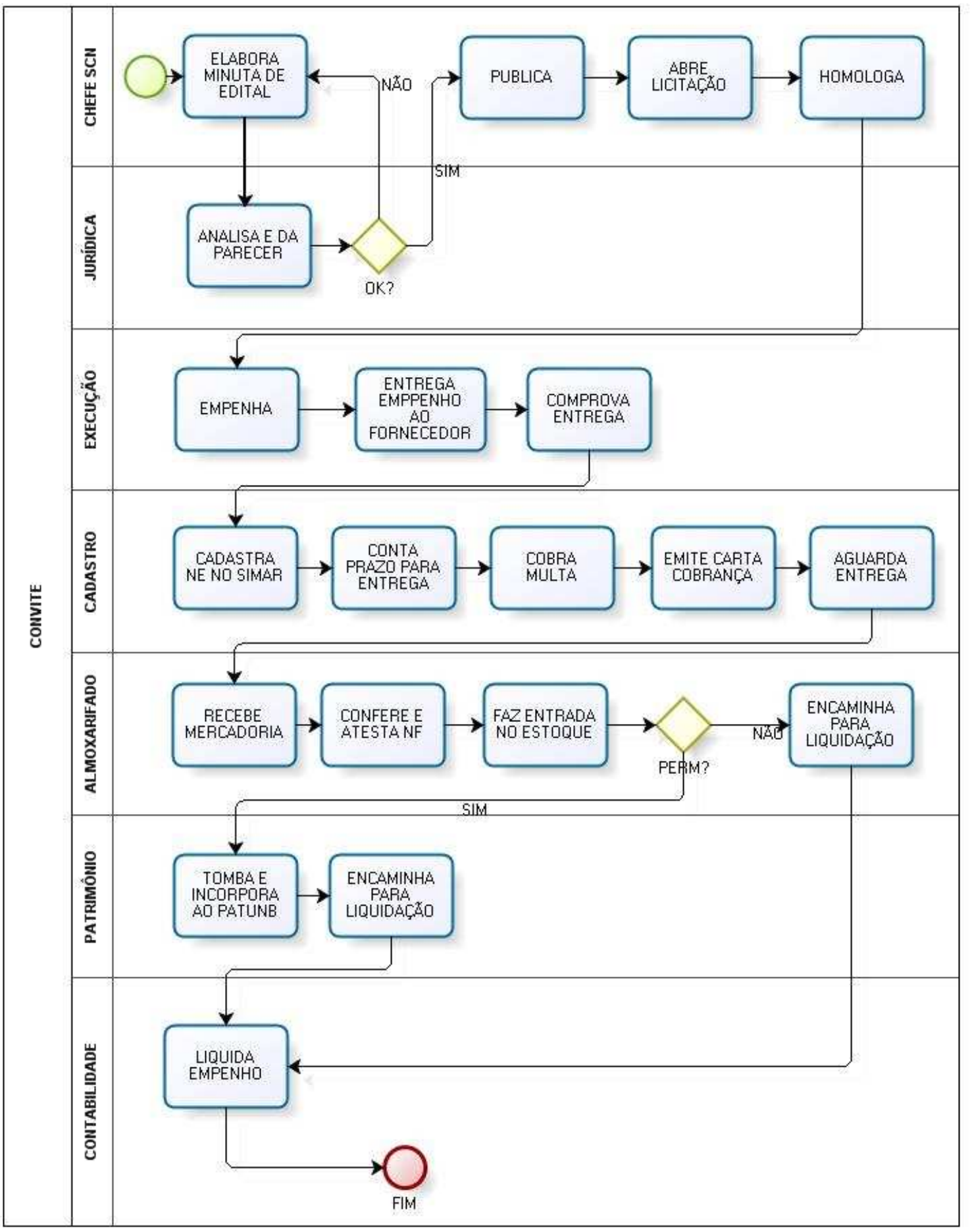

Figura 7B - Convite

Fonte: Elaboração própria 


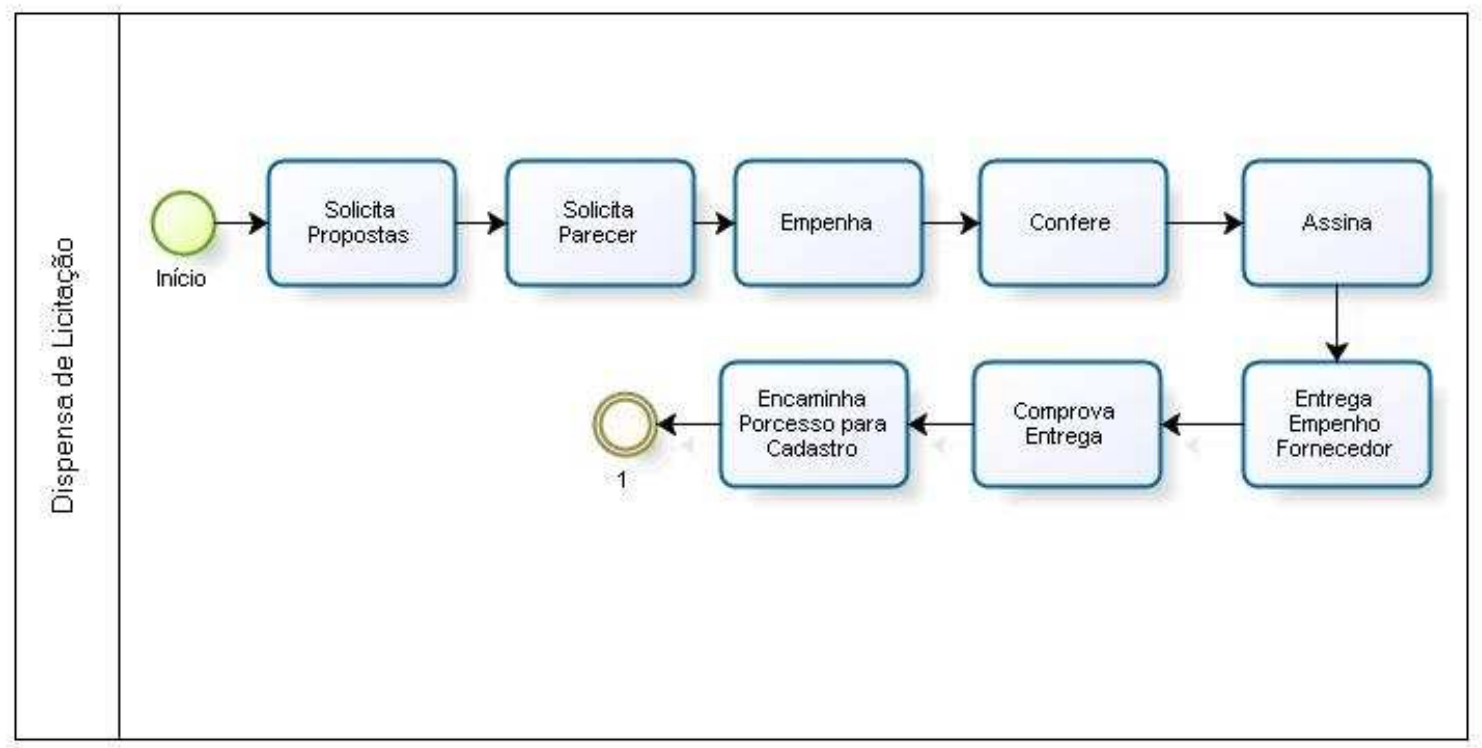

Figura 8A - Dispensa de Licitação

Fonte: Elaboração própria 


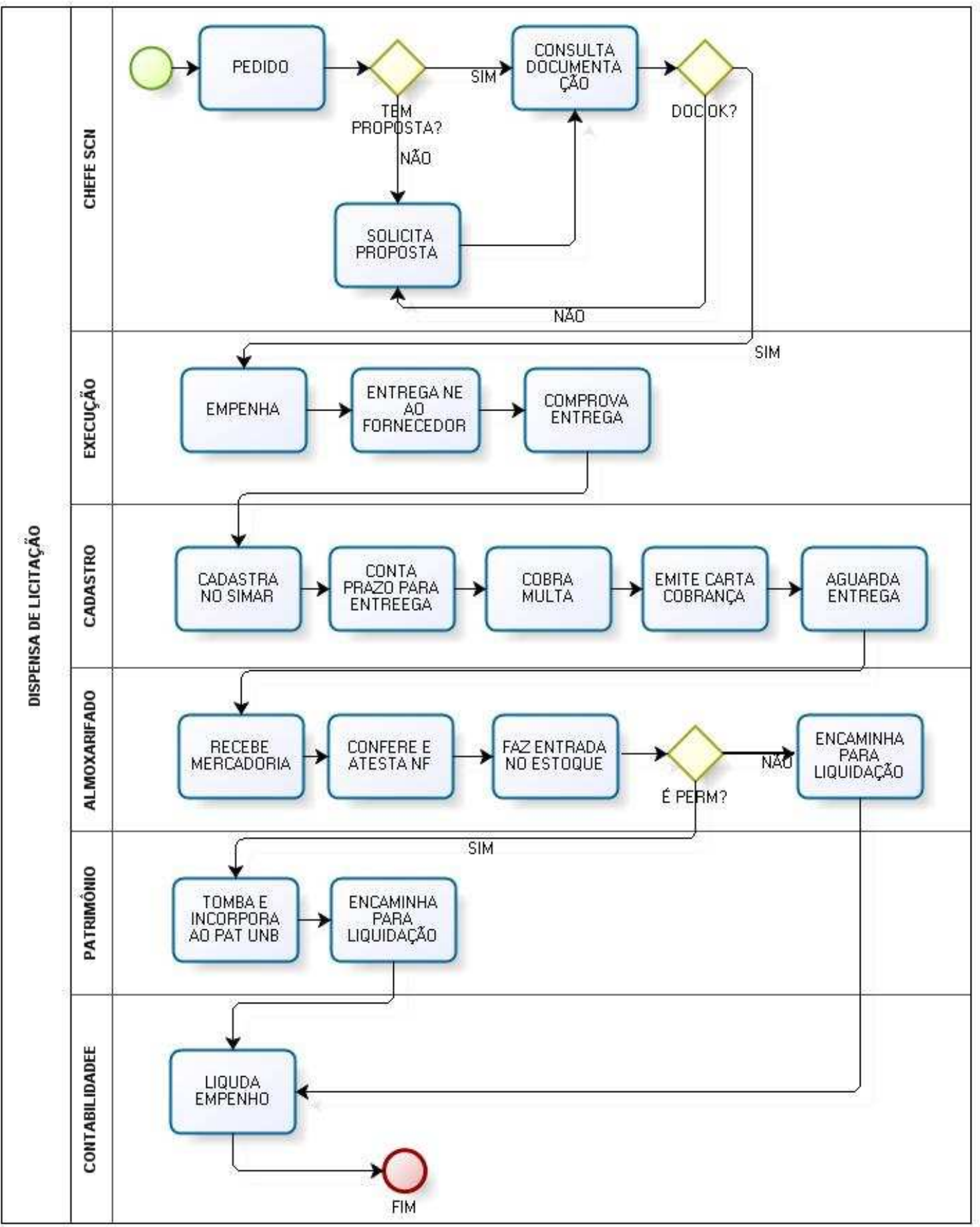

Figura 8B - Dispensa de Licitação

Fonte: Elaboração própria 


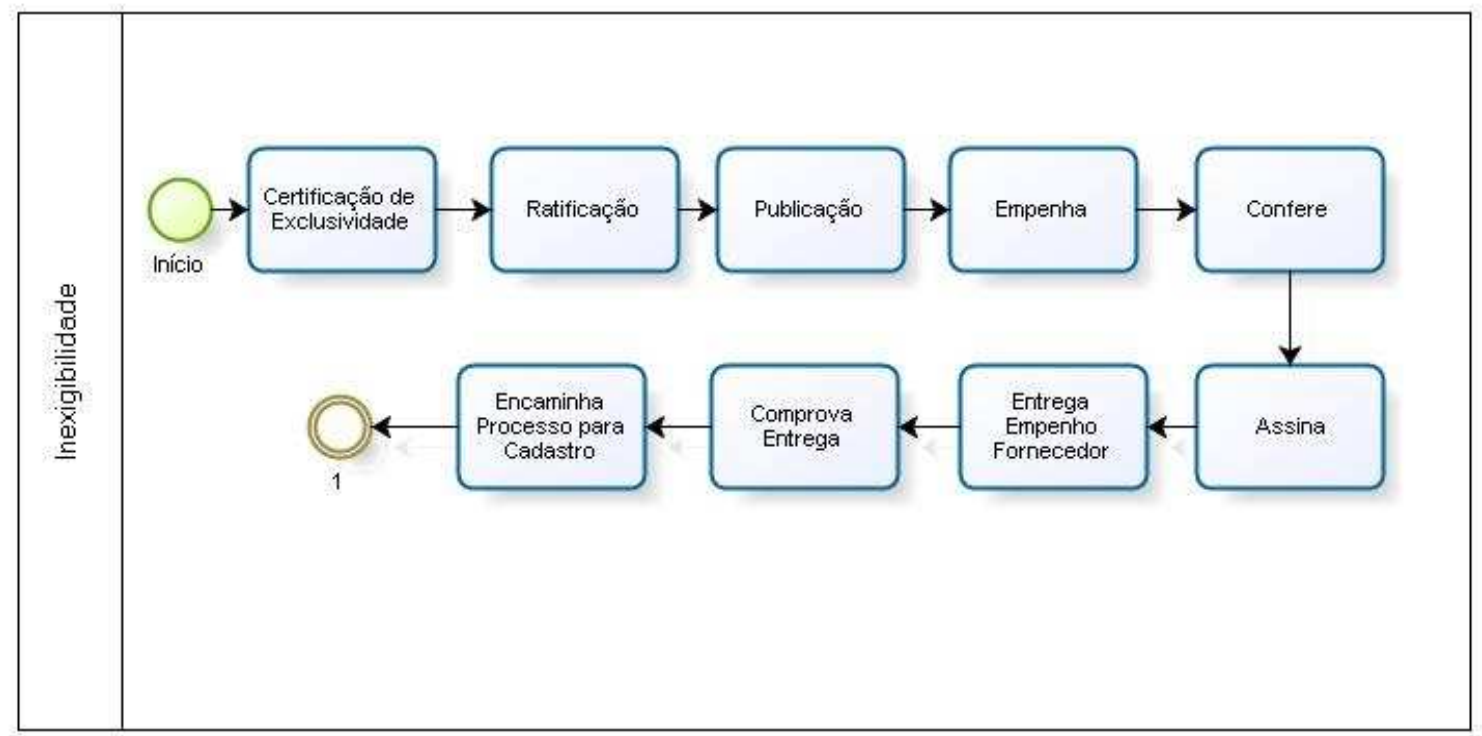

Figura 9A - Inexigibilidade Fonte: Elaboração própria 


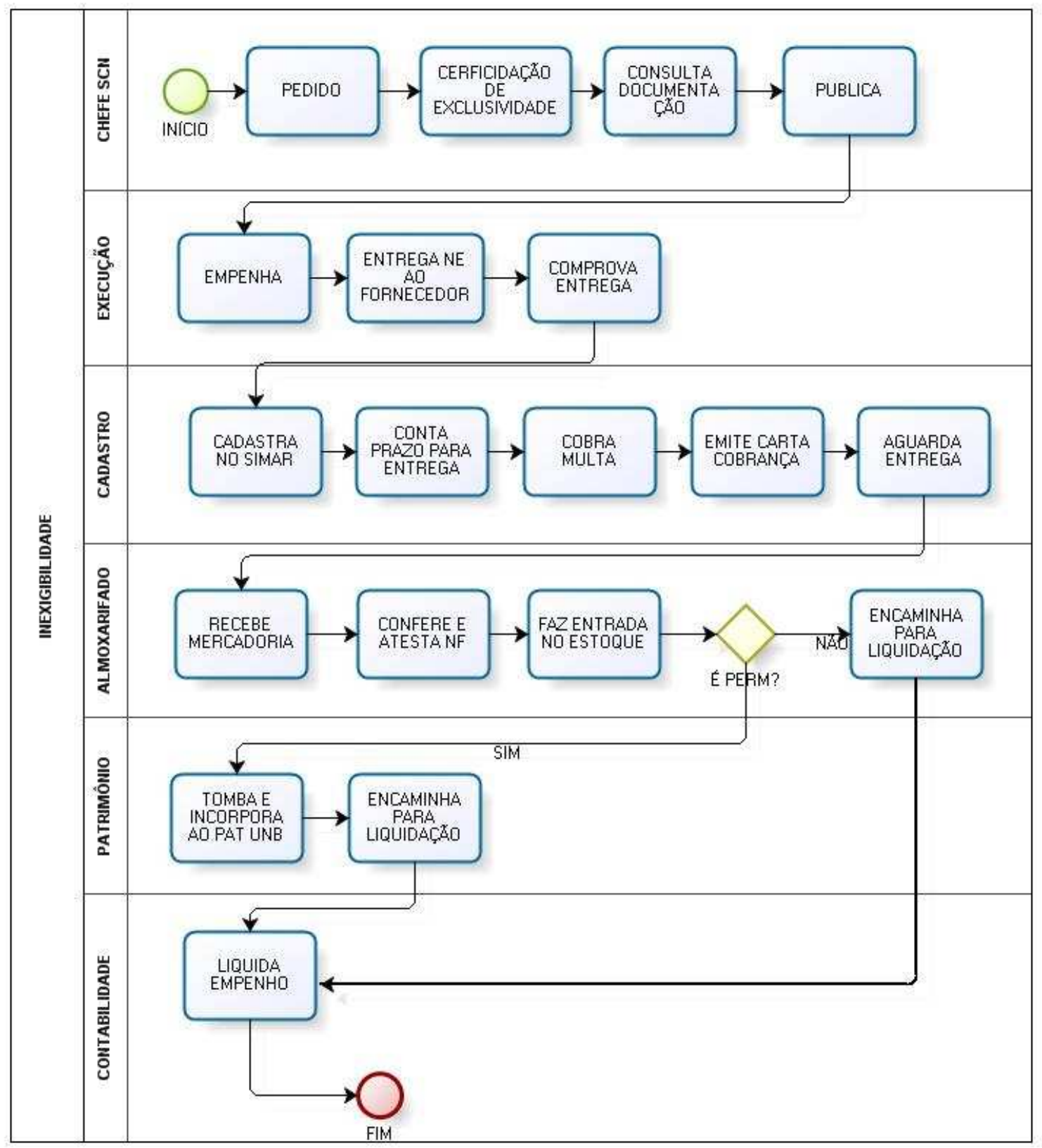

Figura 9B - Inexigibilidade Fonte: Elaboração Própria 


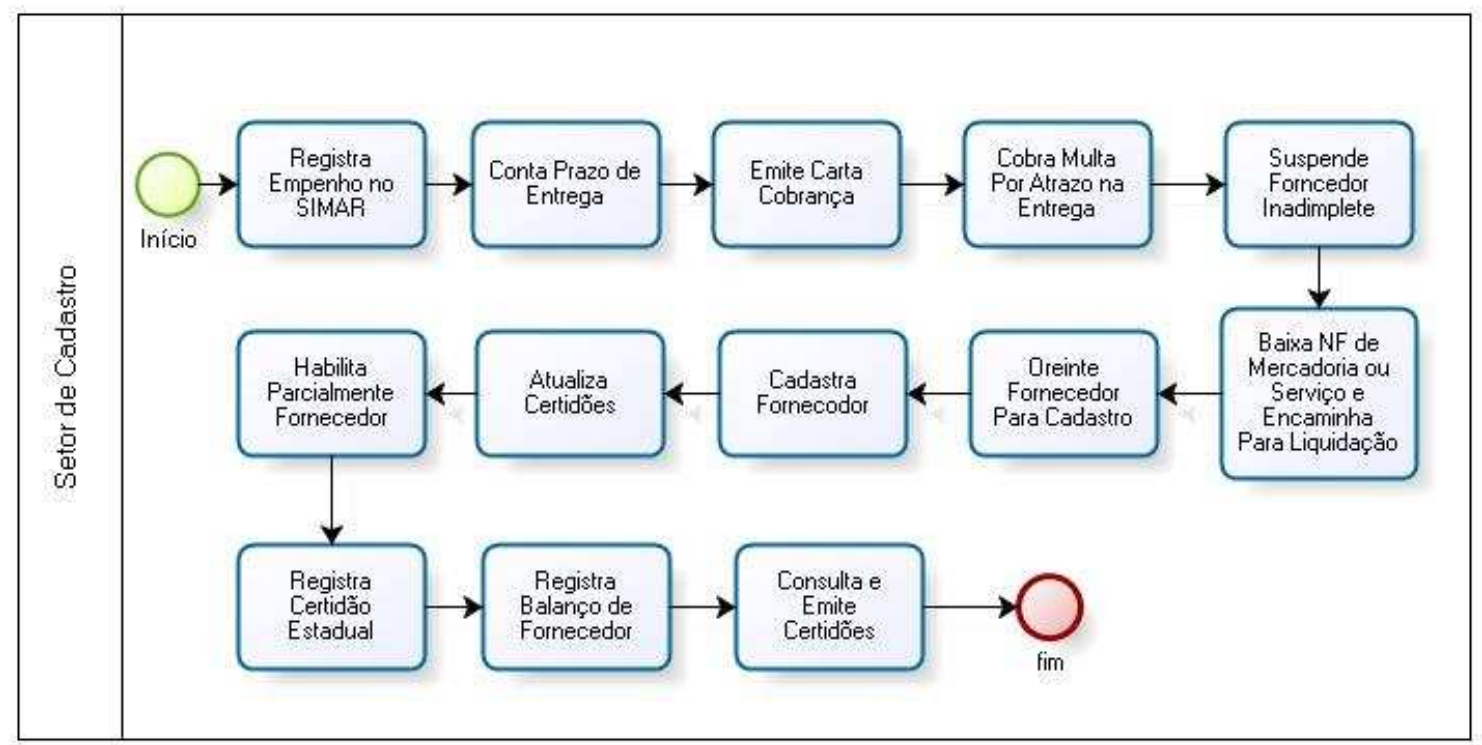

Figura 10 - Setor de Cadastro Fonte: Elaboração própria

A Pesquisa foi realizada no Serviço de Compras Nacionais (SCN) da Universidade de Brasília (FUB), subordinado a Diretoria de Recursos Materiais (DRM) que é subordinado ao Decanato de Administração e Finanças (DAF).

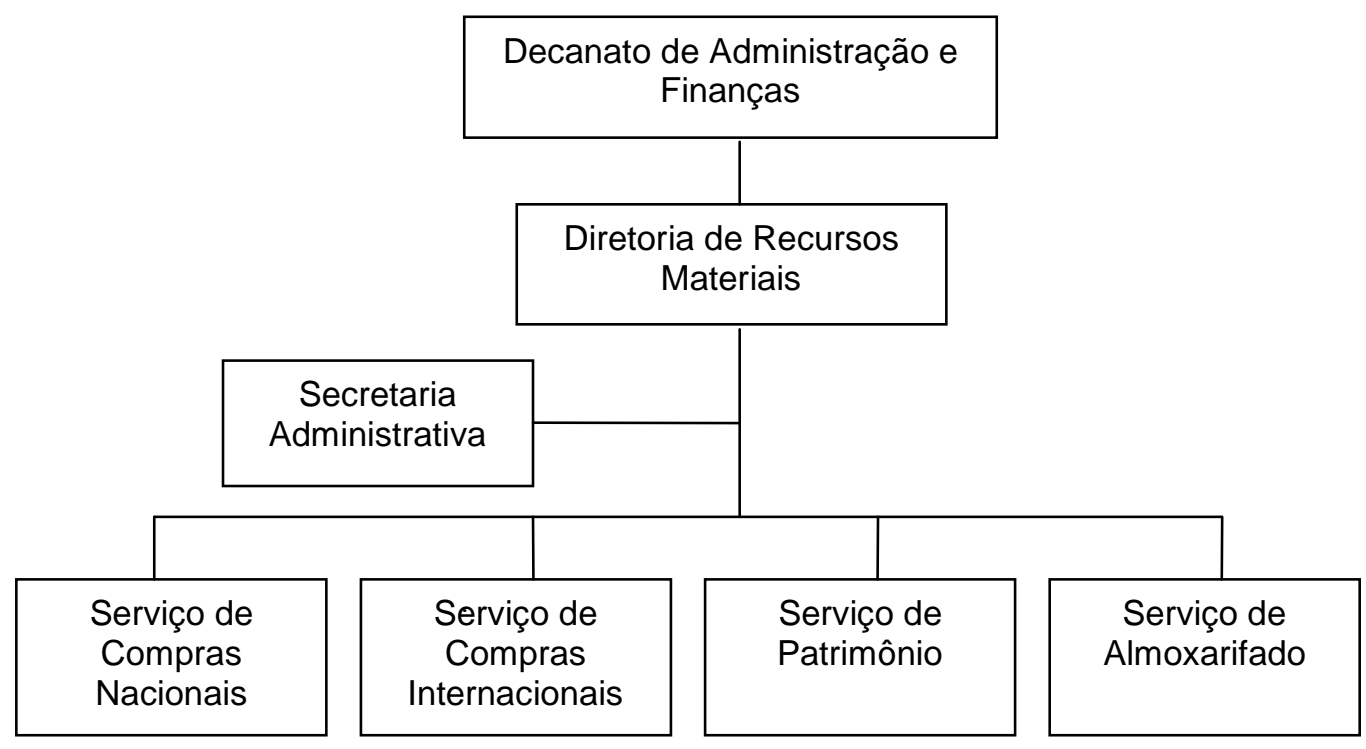

Figura 11 - Organograma do Setor de Compras Fonte: Elaboração própria

Assim, são funções do Serviço de Compras Nacionais: assessorar a Diretoria em assuntos de sua área, manter atualizado o Catálogo de Materiais, emitir documentos para habilitação de fornecedores, atualizar documentos do Cadastro de 
Fornecedores do SICAF, propor à Administração a aplicação da legislação das firmas inadimplentes, e subsidiar a Administração e os Centros de Custo com informações concernentes ao processo de compras no mercado nacional. 


\section{DISCUSSÃO DOS RESULTADOS}

\subsection{Análise dos processos de pedidos de compras das Instituições Federais de Ensino - IFES}

A Universidade Estadual de Campinas (UNICAMP), como já relatado, incorporou a Metodologia de Gestão por Processos na administração e possibilitou a reflexão de maneira estruturada sobre as práticas de compras do cotidiano, facilitando a compreensão por todos da Organização.

Sobre o processo de Compras de pequeno valor conforme art. 24 inc. I e II da lei 8.666/93 na Universidade Estadual de Campinas tem alguma peculiaridades como:

A UNICAMP no seu processo de Compras de Pequeno valor mostra todas as etapas, solicita propostas com indicação clara e precisa sobre a isenção do ICMS, indicação de conta bancária do fornecedor para processar o pagamento, após o pagamento o processo é encaminhado para o Setor de Patrimônio, PROCEDIMENTOS ESPECIAIS: Havendo necessidade de alteração do número da conta e/ou agência bancária do fornecedor, o comprador poderá fazê-lo por ocasião da emissão da Autorização de Fornecimento, devendo, necessariamente, documentar o processo, com os dados bancários completos e em nome do credor, a falta de comprovação das razões que motivarem a alteração da conta e/ou agência, constante da Autorização de Fornecimento, enseja o Órgão Liquidante a não proceder a liquidação da despesa e, conseqüentemente, não efetuar o pagamento e devolver os autos à origem, para sanar a irregularidade procedimental.

Apresentando desta maneira, controle maior sobre os gastos públicos com a compra de materiais por esta Universidade.

$\mathrm{Na}$ Universidade de Brasília as fases do processo são claras, mas existem algumas diferenças em ralação a UNICAMP, como por exemplo: não é informada na solicitação de proposta a exigência quanto à isenção do ICMS, a Nota fiscal de Material Permanente já atestada é encaminhada para pagamento após já ter sido tombado o bem pelo setor de Patrimônio e incorporado o mesmo ao Patrimônio da UnB; enquanto na UNICAMP esse procedimento é após ser efetuado o pagamento, também não é mencionado quanto ao Pedido de Compras de Materiais de pequeno valor, a informação de conta bancária para efeito de pagamento ao fornecedor não 
consta da orientação de compras, não consta dos procedimentos especiais, de alteração do número da conta e/ou agência bancária do fornecedor.

A Universidade Federal de Santa Catarina apresentou um sistema Multiagente SMLP (Sistema Multiagente para Licitação Pública), aplicado ao processo de licitação pública, esse sistema é justificável, pois um processo de licitação pública é naturalmente distribuído sendo composto de três entidades básicas: a empresa ou órgão público que elabora o edital de licitação, os fornecedores que elaboram as propostas e os especialistas que analisam todas as propostas recebidas e apontam um ganhador.

Os dados extraídos da Universidade Federal de Santa Catarina a respeito do processo de compras ainda são precários, pois o sistema utilizado, não abrange todas as modalidades de licitação, apenas a de convite e só alcança as empresas cadastradas e convidadas, as demais só participam se obtiverem informações por terceiros. Esse Sistema para ser bem justificável se faz necessário uma melhor estruturação para atender assim, as demais modalidades de licitação, porem, tem uma peculiaridade importante, onde os agentes participantes do sistema possuem certa autonomia e responsabilidade por cada uma de suas tarefas. executadas e auxiliam os especialistas na tomada de decisão quanto a proposta.mais vantajosa.

De acordo com os dados da Universidade de São Carlos, com a instalação do programa de Requisições foi obtido sucesso de $90 \%$, relacionado ao processo de compra, que oferece uma ferramenta flexível, confiável e ágil.

Tal processo demonstra uma vantagem em relação à solicitação e a aprovação, tendo que passar pelo crivo do Ordenador de despesa e em seguida pela apreciação do Departamento de Controle Orçamentário.

O sistema adotado, então, facilita para os departamentos de almoxarifado e de compra, pois a sua metodologia armazena as informações emitidas não sendo necessária a impressão em papel, gerando economia para Universidade.

A Universidade Federal de Mato Grosso do Sul informa a interação com os usuários e/ou demais órgãos envolvidos para a obtenção de informações, orientam e fiscalizam o processamento de aquisição de materiais quanto às normas legais, promove pesquisa de mercado, elabora plano de compras, presta subsídios quanto às áreas de compras, elabora e expede normas, recebe e classifica os pedidos, 
colabora no plano anual e do orçamento da Gerência, requisita material de consumo e permanente para uso do Departamento, executa a administração Patrimonial, elabora relatórios gerenciais, desenvolve outras atividades dentro de sua área de atuação.

O setor de Cadastro e licitação tem o papel de elaboração do processo licitatório, cadastramento de fornecedores no SIASG/SICA, controle de notas de empenhos/fornecedores nos processos de compras. Analisar a solicitação de compras em relação as especificações, preparar o processo licitatório conforme a modalidade de licitação, publicá-la no SIASG/SIDEC, disponibilizar editais e 0 processo à Comissão Permanente de Licitação - CPL; presta informações aos mesmos sobre cadastramento, interage com os usuários e demais órgãos envolvidos no Sistema para obtenção de informações concernente a fornecedores, materiais ou serviços. Uma vez recebido o processo empenhado, confere e providencia a entrega dos empenhos, controla prazos de entrega, controla o saldo de pagamento através da respectiva ordem bancária, emite carta cobrança junto aos fornecedores e encaminha nota fiscal para pagamento após recebimento do material no almoxarifado central com o devido atesto no verso da nota.

Percebe-se, portanto, que o funcionamento de uma organização de qualquer natureza depende necessariamente da existência de processos. Em empresas de pequeno porte, por exemplo, na maioria dos processos não estão documentados.

Para o sucesso de instituições de maior porte, com diversas áreas funcionais interrelacionadas, é fundamental a utilização de processos documentados, conhecidos, utilizados e continuamente melhorados. A definição de processos, contudo, não é uma tarefa trivial. Um processo bem definido deve indicar papéis, recursos, modelos de referência, procedimentos, métodos, técnicas, ferramentas e atividades a serem executadas.

A manutenção eficiente desses ativos, incluindo a garantia da integridade geral do processo, pode ser uma atividade muito onerosa, complexa e propensa a erros. Por isso, é muito importante prover ferramentas automatizadas para apoiá-la.

A documentação de processos e a sua disponibilização são atividades muito importantes por viabilizar o compartilhamento e a retenção do conhecimento de uma organização. 
Através do processo é possível saber "quem faz o que", "quando" e "como" para que um objetivo seja atingido. Quanto mais amigável for a disponibilização do seu conteúdo, mais fácil será a absorção do conhecimento inserido naquele processo e, conseqüentemente, proporcionará a inovação e a geração de novos conhecimentos, essenciais para o controle e evolução de uma empresa.

Na Universidade de Brasília (UnB), o Pedido de Compras é gerado a partir da emissão do documento de solicitação de compras autorizado pelo titular do Centro de Custo, pelo Coordenador do Curso de Pós-Graduação ou pelo executor do convênio e encaminhado à Diretoria de Recurso Materiais (DRM).

Suas fases acontecem da seguinte maneira: é recebido na DRM através de sua Secretaria administrativa onde é feito o seu registro no UNBDOC, onde o Diretor da DRM confirma a disponibilidade orçamentária; se não há, devolve o pedido ao solicitante, verifica se o pedido está discriminado corretamente, se não, o devolve ao solicitante para providenciar a correção, e, em se tratando de equipamentos de informática e aparelho de ar condicionado não contemplados pela padronização da FUB, serão encaminhados ao CME, para a devida especificação; relaciona pedidos para fins de aquisição em lotes, especificamente quando se trata de equipamentos de informática, móveis, equipamentos de laboratórios e equipamentos de áudio/vídeo/som/imagens, devido ao grande volume de compras. Os demais grupos de materiais são adquiridos de acordo com a demanda; providencia avaliação de preços estimados junto ao mercado para definir a modalidade da licitação em conformidade com a lei e em atendimento à recomendação do TCU; quando a modalidade de licitação a ser executada é do tipo convite conforme art. 23 inciso II alínea a da lei 8.666/93, ou de dispensa conforme art. 24, inciso II, da lei 8.666/93, ou ainda, para aquisição de bens destinados exclusivamente a pesquisa científica e tecnológica.

A seguir o quadro comparativo entre os processos pesquisados nas Instituições Federais de Ensino Superior - IFES. 


\begin{tabular}{|c|c|c|c|c|c|}
\hline & UNICAMP & UFSC & UFSCAR & UFMGS & UnB \\
\hline $\begin{array}{l}\text { Estado } \\
\text { atual do } \\
\text { Processo } \\
\text { de } \\
\text { Compras }\end{array}$ & $\begin{array}{l}\text { Incorporou a } \\
\text { Metodologia } \\
\text { de Gestão por } \\
\text { processos }\end{array}$ & $\begin{array}{l}\text { Apresentou o } \\
\text { Sistema } \\
\text { Multiagente } \\
\text { para Licitação } \\
\text { Pública SMLP }\end{array}$ & $\begin{array}{l}\text { Instalação do } \\
\text { programa de } \\
\text { Requisições }\end{array}$ & $\begin{array}{l}\text { Interação com } \\
\text { os usuários e os } \\
\text { demais órgãos } \\
\text { envolvidos. }\end{array}$ & $\begin{array}{l}\text { O pedido de compras } \\
\text { deve ser emitido pelo } \\
\text { sistema SIMAR na } \\
\text { tela pedido de } \\
\text { compras }\end{array}$ \\
\hline $\begin{array}{l}\text { Melhorou a } \\
\text { qualidade } \\
\text { de sua } \\
\text { equipe de } \\
\text { processo } \\
\text { de compras }\end{array}$ & $\begin{array}{l}\text { Ampliou o } \\
\text { curso de } \\
\text { formação de } \\
\text { facilitadores } \\
\text { com } 32 \text { horas } \\
\text { pra outro de } \\
\text { equipes } \\
\text { multidisciplinar } \\
\text { es com } 100 \\
\text { horas }\end{array}$ & $\begin{array}{l}\text { Composto de } \\
\text { três entidades } \\
\text { básicas: as } \\
\text { empresas ou } \\
\text { órgãos } \\
\text { públicos, os } \\
\text { fornecedores e } \\
\text { os } \\
\text { especialistas } \\
\text { que analisam } \\
\text { as melhores } \\
\text { propostas. }\end{array}$ & $\begin{array}{l}\text { Informa que } \\
90 \% \text { do } \\
\text { sucesso está } \\
\text { relacionado a } \\
\text { elaboração do } \\
\text { pedido de } \\
\text { compras }\end{array}$ & $\begin{array}{l}\text { Orientam e } \\
\text { fiscalizam o } \\
\text { processamento } \\
\text { de aquisição de } \\
\text { materiais quanto } \\
\text { as normas } \\
\text { legais. }\end{array}$ & $\begin{array}{l}\text { Antes da emissão do } \\
\text { pedido o site } \\
\text { WWW.compras.unb.b } \\
\text { r deve ser consultado } \\
\text { para verificar a } \\
\text { existência de bens e } \\
\text { serviços licitados por } \\
\text { meio do Sistema de } \\
\text { Registro de Preços - } \\
\text { SRP implementado } \\
\text { pela DRM }\end{array}$ \\
\hline $\begin{array}{l}\text { Fator } \\
\text { positivo e } \\
\text { negativo do } \\
\text { processo } \\
\text { de compras }\end{array}$ & $\begin{array}{l}\text { A } \\
\text { compreensão } \\
\text { por todos da } \\
\text { organização }\end{array}$ & $\begin{array}{l}\text { O fator } \\
\text { negativo: só } \\
\text { utilizado para a } \\
\text { modalidade de } \\
\text { convite. }\end{array}$ & $\begin{array}{l}\text { Facilidade para } \\
\text { os } \\
\text { departamentos, } \\
\text { de } \\
\text { almoxarifado e } \\
\text { de compras }\end{array}$ & $\begin{array}{l}\text { Promove } \\
\text { pesquisa de } \\
\text { mercado para as } \\
\text { compras, elabora } \\
\text { plano de } \\
\text { compras. }\end{array}$ & $\begin{array}{l}\text { Providencia avaliação } \\
\text { de preços estimados } \\
\text { junto ao mercado. E } \\
\text { Equipamentos de } \mathrm{Ar} \\
\text { condicionado e de } \\
\text { informática são } \\
\text { especificados pelo } \\
\text { CME }\end{array}$ \\
\hline $\begin{array}{l}\text { Melhorou } \\
\text { controle e } \\
\text { economia } \\
\text { para as } \\
\text { instituições }\end{array}$ & $\begin{array}{l}\text { Maior controle } \\
\text { sobre os } \\
\text { gastos } \\
\text { públicos }\end{array}$ & $\begin{array}{l}\text { Pode ser } \\
\text { melhorado } \\
\text { para outras } \\
\text { modalidades } \\
\text { no futuro. }\end{array}$ & $\begin{array}{l}\text { armazena as } \\
\text { informações } \\
\text { emitidas, não } \\
\text { sendo } \\
\text { necessária a } \\
\text { impressão em } \\
\text { papel, gerando } \\
\text { economia para } \\
\text { a Universidade }\end{array}$ & $\begin{array}{l}\text { Elabora e } \\
\text { expede normas, } \\
\text { recebe e } \\
\text { clássica pedidos, } \\
\text { colabora no } \\
\text { plano anual e do } \\
\text { orçamento da } \\
\text { Gerência }\end{array}$ & $\begin{array}{l}\text { A aquisição externa } \\
\text { de materiais de } \\
\text { consumo que são } \\
\text { mantidas em } \\
\text { estoque, não é } \\
\text { permitida, exceto, } \\
\text { quando se trata de } \\
\text { recursos oriundos de } \\
\text { órgãos de fomento à } \\
\text { pesquisa cientifica e } \\
\text { tecnológica }\end{array}$ \\
\hline
\end{tabular}

Quadro 5 - Comparativo dos processos de compras das IFES, pesquisados.

Fonte: Elaboração própria

\subsubsection{Um modelo de processo de compras}

Gonçalves (2000) destaca que o pensamento de processo como um fluxo de trabalho com inputs e outputs claramente fixados e atividades discretas que possuem uma seqüência e dependem umas das outras numa ordem clara vem da tradição da engenharia. Nessa abordagem, os processos também têm começo e fim bem estabelecidos.

Entretanto, como Gonçalves (2000) relembra, o fluxo de trabalho trata de apenas um dos tipos de processo empresarial, talvez aquele em que as tarefas são mais interdependentes e realizadas numa sucessão específica. Essa definição 
restrita, então, não abrange os processos que não têm início e fim bem definidos ou cujo fluxo não é bem claro.

No caso dos processos de compras suas etapas são claras, bem definidas e dependem umas das outras numa seqüência lógica, com: entrada do pedido de compras, análise do mesmo, cotação de preços, elaboração de editais, processamento da licitação, escolha da melhor proposta, empenho até o final com a entrega do bem ou serviço comprado ao solicitante.

Coulson-Thomas (1996) apud Monteiro (2003, p. 17-8) definem que as organizações devem possuir habilitações para serem orientadas em processos, como:

Eliminar as fronteiras interdepartamentais, de modo que as atividades sejam executadas de acordo com um modelo horizontal baseado em processos e não em tarefas especializadas executadas por departamentos estanques. Levar em conta que os processos de uma organização interagem tanto interna quanto externamente;

Definir equipes multifuncionais para cuidarem do processo do início ao fim, com autonomia para tomada de decisões e responsabilidade pelos resultados;

Estimular a comunicação interpessoal e o aprendizado e recompensar 0 desempenho

Obter o comprometimento de todos com a nova orientação, em especial da alta administração.

Nos últimos tempos as instituições estão numa busca constante por um modelo de processo eficiente que atinja o seu objetivo proposto com qualidade, agilidade, menor custo, menor tempo e levando satisfação ao seu cliente final. Para tanto é necessário implementar esforços na contratação de uma equipe detentora de conhecimento e ferramentas específicas na simulação e detecção de gargalos indicando onde devem ocorrer a melhoria e até mesmo propor um novo processo, caso seja realmente necessário.

Davenport (1994) apud Monteiro (2003, p. 42-6) aponta os seguintes habilitadores da reengenharia de processos:

Alinhamento com a estratégia: pois, de acordo com o autor, a reengenharia de processos deve estar estreitamente ligada à estratégia da organização. Devendo 
então, estabelecer quais processos serão reestruturados, e as metas de desempenhos que deverão ser atingidas.

Metodologia: o autor descreve que dificilmente a reengenharia de processos obterá sucesso sem um direcionamento metodológico que sistematize e otimize os esforços a serem alocados em cada proposta de reengenharia. Assim, para Davenport (1994) a reengenharia de processos pode ser implementada conforme as etapas abaixo:

a) Identificação dos processos para reengenharia: nessa fase procura-se identificar quais os processos que a organização possui, para que se possa priorizar os que serão candidatos à reengenharia

b) Identificação das ferramentas de mudança: Davenport, então, salienta que nesta etapa há a identificação dos habilitadores organizacionais e de recursos humanos que serão utilizados, assim como o gerenciamento de mudança.

c) Definição dos objetivos e características do processo: esta etapa possui o ideal de se alinhar o processo à estratégia organizacional, como as metas de desempenho que se pretende atingir (custo, qualidade, velocidade, flexibilidade e confiabilidade), além de especificações que devem estar presentes na operação do processo, como a tecnologia a ser utilizada, gerenciamento do processo por equipes multifuncionais e autogeridas, agrupamento das atividades do processo em um único local.

d) Compreensão do processo existente: neste momento busca-se entender o funcionamento do processo, além das oportunidades de melhoria, tendo como base os objetivos de desempenho e os atributos especificados para o novo processo.

e) Projeto e protótipo do novo projeto: desenvolvimento e implementação do novo processo.

Incorporar a Metodologia de Gestão por processos a exemplo da Universidade Estadual de Campinas (UNICAMP) onde possibilitou a reflexão de maneira estruturada sobre as práticas do dia a dia facilitando a compreensão por todos da Organização 
Reorganizar e melhorar seus processos, visando responder às mudanças, maximizar as oportunidades e atender seus clientes/usuários da melhor forma buscando sua satisfação.

Implantar cursos de formação de facilitadores, incluir disciplinas que trata de desenvolvimento de pessoal, visando o engajamento individual das pessoas a partir do conhecimento e compreensão do que se deseja de cada um, essencial para obtenção dos resultados globais esperados pela instituição. 


\section{CONCLUSÃO}

Diante da complexidade de se analisar processos e a dificuldade de seu entendimento, faz-se necessário em algumas situações o seu mapeamento, mostrando passo a passo o seu comportamento ao longo de sua trajetória, como a entrada de pedidos devidamente justificados, com informação de recursos para sua execução até a etapa final de entrega do empenho com o recebimento do material ou serviço objeto da compra.

A pesquisa foi feita nas Universidades por meio eletrônico em suas páginas na internet, somente a Universidade de Brasília o acesso foi feito por meio eletrônico e consulta em alguns documentos manuais.

Nota-se, portanto, que os processos não diferem muito uns dos outros, porém em algumas Instituições, como a UNICAMP, são melhores definidos e suas etapas são mais claras, tornando-os mais ágeis e menos burocráticos, também a Universidade de São Carlos, com a instalação do programa de Requisições foi obtido sucesso de $90 \%$, relacionado ao processo de compra, que oferece uma ferramenta flexível, confiável e ágil

Os processos de uma organização nem sempre são melhores do que de outras, apenas existem os que são acompanhados e melhorados constantemente, esses sim, são ditos os que melhor satisfazem e atendem à necessidade organizacional atual.

Na Universidade de Brasília (UnB), o Pedido de Compras é gerado a partir da emissão do documento de solicitação de compras autorizado pelo titular do Centro de Custo, pelo Coordenador do Curso de Pós-Graduação ou pelo executor do convênio e encaminhado à Diretoria de Recurso Materiais (DRM). Essas informações são encontradas na página da DRM na internet.

As compras da Universidade de Brasília são executadas em conformidade com a legislação vigente, a lei 8.666, de 21 de junho de 1993 e a 10.520, de 17 de julho de 2002, que denominou a modalidade de licitação pregão para a aquisição de bens e serviços comuns.

O objetivo desta pesquisa foi de propor a elaboração de um processo uniformizado de aquisição de compras de materiais e serviços adequados às necessidades da UnB. 
Para tanto se buscou informações através de pesquisa em outras instituições federais de Ensino Superior do Brasil em suas páginas na internet, para balizar e comparar os processos de compras destas Instituições com o da UnB.

Análise comparativa foi para tirar como base o melhor processo para torná-lo como modelo a ser aplicado aqui nesta Instituição, com as devidas adaptações e melhorias que se fizerem necessárias.

É importante, deste modo, se fazer pesquisas mais aprofundadas em diferentes empresas, sejam elas privadas ou públicas para que se possa conhecer a eficiência e efetividade na execução dos processos e analisar seu desempenho através de uma administração por processos, por meio de descrição mais detalhada de suas diferentes etapas de execução. 


\section{REFERÊNCIAS}

ANDRADE, A. R. Comportamento e estratégias de organizações em tempos de mudança sob a perspectiva da tecnologia da informação. Caderno de Pesquisas em Administração, São Paulo, v. 09, n. 2, abril/junho 2002. Disponível em: $<$ http://www.granol.com.br/luizsergio/7t/artigo2.pdf >. Acesso em: 10/03/2009.

ARAUJO, J.S. Administração de Compras e Armazenamento. 2.ed. São Paulo: Atlas, 1976.

BALLOU, R. H. Logística empresarial: transporte, administração de materiais distribuição física. São Paulo: Atlas, 1993.

BRASIL. Lei no 10.520, de 17 de julho de 2002. Institui, no âmbito da União, Estados, Distrito Federal e Municípios, nos termos do art. 37, inciso XXI, da Constituição Federal, modalidade de licitação denominada pregão, para aquisição de bens e serviços comuns, e dá outras providências. Secretaria de Estado de Planejamento e Gestão do DF, 2009. Disponível em: $<$ http://sileg.sga.df.gov.br/default.asp?arquivo=http\%3A//sileg.sga.df.gov.br/legislaca o/Federal/Leis\%2520federais/lei 10520 02.htm>. Acesso em: 10/01/2009.

BRASIL. Lei $\mathrm{n}^{\circ}$ 8.666, de 21 de julho de 1993. Licitações e contratos administrativos: consolidação determinada pelo art. $3^{\circ}$ da Lei $n^{\circ}$ 8.883/94 e publicada no Diário Oficial da União de 6.7.94 / organizado por Cerdônio Quadros, Marcello Rodrigues Palmieri e Centro de Estudos de Direito Administrativo da NDJ. -22 ed. Atual. São Paulo: Editora NDJ, 2005.

BRASIL. SIASG/ Comprasnet: a tecnologia da informação na gestão das compras governamentais na administração pública federal brasileira. Brasília: Ministério do Planejamento, Orçamento e Gestão, 2002.

Campos, E. R. Metodologia de Gestão por Processos. Campinas : UNICAMP, 2007. Disponível em: $<$ http://www.prdu.unicamp.br/gestão por processos/gestão processos.html>. Acesso em: 10/04/2009.

CARAVANTES, G. R.; CARAVANTES, C. B.; BJUR, W. E. Administração e qualidade: a superação dos desafios. São Paulo: Makron Books, 1997.

CAVINATO.J. L; and KAUFFMAN. R. G. The Purchasing Handbook: A Guide for the Purchasing and Supply Professional. 6th. ed. McGraw-Hill, 2000.

CORREIA; A. Aplicação da técnica de mapeamento de fluxo de processo no diagnóstico do fluxo de informações da cadeia cliente-fornecedor. Curitiba, 2002.

DAVENPORT, T. H. Reengenharia de processos: como inovar na empresa através da tecnologia da informação. Rio de Janeiro: Campus, 1994.

DEMO, P. Metodologia do Conhecimento Científico. São Paulo: Atlas, 2000. 
FERNANDES, C. C. C. Impactos dos sistemas de compras governamentais eletrônicas na administração pública: algumas evidências recentes da experiência brasileira. Trabalho apresentado no IX Congreso Internacional del CLAD sobre la Reforma del Estado y de la Administración Pública, Madrid, España, 2 - 5 Nov. 2004.

FONSECA, M. A. Pregão Eletrônico: Uma análise de sua aplicabilidade e eficácia na Administração Pública Federal. Campinas: Ed. Impactus, 2007.

FUSCO, J. P.A. Tópicos emergentes de engenharia de produção. V.3. São Paulo: Arte \& Ciência, 2005.

GIL, A. C. Métodos e Técnicas de Pesquisa Social. .São Paulo. Atlas, 1994.

GONÇALVES, J. E. L. As empresas são grandes coleções de processos. Revista de Administração de Empresas, São Paulo, v. 40, n. 1, janeiro/março. 2000. Disponível em: <http://www.fgvsp.br/rae/artigos/006-019.pdf>. Acesso em: 05/03/2009.

GONÇALVES, J. E. L. Processo, que processo? Revista de Administração de Empresas, São Paulo, v. 40, n. 4, out./dez. 2000. Disponível em: <http://www.fgvsp.br/rae/artigos/006-019.pdf>. Acesso em: 05/03/2009.

MENEZES, A. M. F. Fonseca, M. J. M. Governo eletrônico: um novo caminho para a administração pública? Análise \& Dados, Salvador, v. 15, n. 2-3, p. 333-341, 2005.

MENEZES, R. A.; SILVA, R. B.; LINHARES, A. Leilões eletrônicos reversos multiatributo: abordagem de decisão multicritério aplicada às compras públicas brasileiras. RAC, v.11, n. 3, jul/set. 2007.

MONTEIRO, W. R. Implementação da reengenharia de processos do negócio: estudo de casos de organizações no Brasil. São Paulo: 2003. 127 f. Dissertação de mestrado- Departamento de Administração. Universidade de São Paulo. Disponível em: $\quad<$ http://www.teses.usp.br/teses/disponiveis/12/12139/tde-20122004-142617/>. Acesso em: 10/03/2009.

MORGAN, G. Imagens da organização. São Paulo : Atlas, 1995.

NEIBUHR, J. M. As vantagens da modalidade pregão. 2004 Disponível em: <http://www.mnadvocacia.com.br/assets/pdf/artigo pregao.pdf>.Acesso em:10/04/2009.

OBOLENSKY, N. Guia Prático de Reengenharia. Rio de Janeiro: Record, 1996.

OLIVEIRA, G. A. de: SCHWANKE, T. L., LANCGE, E. M.; MAEHLER, A. E. Economia do Setor Público Utilizando o Pregão Eletrônico: o caso da UFPEL. Disponível em: <http;//www.ufpel.tche.br/cic/2007/cd/pdf/SA/SA_02044.pdf - >. Acessado em 27/ 02/ 2009.

RODRIGUES, M.V. Processo de melhoria nas organizações brasileiras. Rio de Janeiro : Qualitymark, 1999. 
RUMMLER, G. A. ; BRACHE, A. P. Melhores Desempenhos das Empresas: ferramentas para a melhoria da qualidade e da competitividade. São Paulo: Ed. Makron Books, 1992.

SALDANHA, C. Introdução à Gestão Pública. São Paulo: Saraiva, 2006.

SANTOS, A. R. Metodologia Científica: Construção do Conhecimento, RJ, DP\&A Editora, 1999.

SANTOS, E. G.; CERANTE, L. L. Gestão do Conhecimento: um estudo para facilitar sua implantação nas empresas. Rio de Janeiro: 2000. $131 \mathrm{f}$. Monografia em Ciência da Computação- Departamento de Ciência da Computação. Universidade Federal do Rio de Janeiro. Disponível em: $<$ http://dataware.nce.ufri.br:8080/dataware/publicacoes/dataware/fisico/projetosFinai s/gestaodoconhecimento/SANTOS-CERANTE-2000.pdf>. Acesso em: 08/03/2009.

SILVA,S. L.Informação e competitividade: a contextualização da gestão do conhecimento nos processos organizacionais. 2000. Disponível em: $<$ http://www.scielo.br/scielo.php?pid=S0100-

196519652002000200015\&script=sci_arttext\&tIng=pt>;. Acesso em: 10/02/2009.

TACHIZWA,T. Organização Flexível: qualidade na gestão do processo. São Paulo: Atlas, 1997.

TREVINE at al.. Iniciar a Gestão por processo. Campinas: Universidade Estadual de Campinas, $2006 . \quad$ Disponível em: $<$ http://www.dga.unicamp.br/Arquivos/Pdf/IniGesProTexRef.pdf $\quad>$.Acesso em: 30/11/2008.

VERGARA, S.C. Começando a definir a metodologia. In: Projeto e relatórios de pesquisa em administração.3 ed. São Paulo: Atlas, 2000, cap.4.

VILLELA, C.S.S. Mapeamento de Processos como ferramenta de reestruturação e aprendizado. Florianópolis, 2000. 